\title{
Metal(loid) exposure assessment and biomarker responses in captive and free-ranging European brown bear (Ursus arctos)
}

\author{
Maja Lazarus $^{\mathrm{a}, *}$, Tatjana Orct ${ }^{\mathrm{a}}$, Agnieszka Sergiel ${ }^{\mathrm{b}}$, Lana Vrankovićc Vlatka Filipović Marijić $^{\mathrm{d}}$, \\ Dubravka Rašića $^{\text {, Slaven Reljićc }}{ }^{\text {, Jasna Aladrovićc }}{ }^{c}$, Tomasz Zwijacz-Kozica ${ }^{\mathrm{e}}$, Filip Zięba ${ }^{\mathrm{e}}$, \\ Jasna Jurasovića ${ }^{\text {, Marijana Erk }}{ }^{\mathrm{d}}$, Robert Maślak ${ }^{\mathrm{f}}$, Nuria Selva ${ }^{\mathrm{b}}$, Đuro Huber ${ }^{\mathrm{b}}$ \\ ${ }^{a}$ Institute for Medical Research and Occupational Health, Zagreb, Croatia \\ ${ }^{\mathrm{b}}$ Institute of Nature Conservation, Polish Academy of Sciences, Kraków, Poland \\ ${ }^{\mathrm{c}}$ Faculty of Veterinary Medicine, University of Zagreb, Zagreb, Croatia \\ ${ }^{\mathrm{d}}$ Ruđer Bošković Institute, Zagreb, Croatia \\ e Tatra National Park, Kuźnice, Poland \\ ${ }^{\mathrm{f}}$ Institute of Environmental Biology, University of Wrocław, Wrocław, Poland
}

\section{A R T I C L E I N F O}

\section{Keywords:}

Blood

Hair

Terrestrial mammal

Oxidative stress

Elements

\begin{abstract}
A B S T R A C T
We investigated the level of five non-essential metal(loid)s (As, Cd, $\mathrm{Hg}, \mathrm{Tl}, \mathrm{Pb}$ ) and nine essential metals ( $\mathrm{Mg}$, Ca, $\mathrm{Mn}, \mathrm{Fe}, \mathrm{Co}, \mathrm{Cu}, \mathrm{Zn}, \mathrm{Se}, \mathrm{Mo}$ ) in hair and blood components of captive and free-ranging European brown bear populations in Croatia and Poland. Metal(loid) associations with biomarkers of oxidative stress (superoxide dismutase, SOD; glutathione-peroxidase, GSH-Px; malondialdehyde, MDA) and metal exposure (metallothionein, MT) were estimated in this top predatory mammal. Lead was the most abundant non-essential metal(loid) in both blood and hair, with 4 of 35 individuals having blood levels over $100 \mu \mathrm{g} / \mathrm{L}$. A positive association was found between $\mathrm{Pb}$ level and SOD activity in blood. Free-ranging bears had higher blood SOD activity, Mn, Zn and Cd levels, hair $\mathrm{Co}, \mathrm{Cd}, \mathrm{Tl}$ and $\mathrm{Pb}$ compared to captive individuals, while the opposite was true for $\mathrm{Mg}$ and hair $\mathrm{Ca}$ thereby reflecting habitat and diet differences. With increasing age, animals showed lower levels of SOD activity and certain essential metals. Females had higher SOD activity and blood levels of some essential metals than males. Hair showed a higher Fe and Co level when sampled during the growth phase and was not predictive of non-essential metal(loid) blood levels. The established metal(loid) baseline values will enable future risk assessment in both captive and wild European brown bear populations.
\end{abstract}

\section{Introduction}

Due to their trophic position, apex predators are known to face elevated health risks due to the long-range transport of metal-bearing particles, and the persistence and accumulation of inorganic pollutants along the food chain (Burger et al., 2007; Rodríguez-Jorquera et al., 2017, Rodríguez-Estival and Mateo, 2019). In particular, non-essential metal(oid)s (arsenic, cadmium, lead, and mercury) are health stressors known to adversely impact large terrestrial mammals (Reglero et al., 2009, Rodríguez-Estival et al., 2011; Berzas Nevado et al., 2012; Tchounwou et al., 2012, Rodríguez-Estival et al., 2013). These metal (oid)s have been demonstrated to impair homeostasis of essential metals, leading to their deficiency or surplus (Goyer, 1997; Reglero et al., 2009; Durkalec et al., 2018; Kalisińska, 2019), and their impacts can also be reflected as perturbations in oxidative stress biomarkers.

Metals induce oxidative stress causing toxic effects through the depletion of major antioxidants (e.g., glutathione, metallothionein), changes in the activity of antioxidative enzymes (e.g., glutathioneperoxidase, superoxide-dismutase) and free radical levels that can damage biomolecules (DNA, proteins, membrane lipids) (Stohs and Bagchi, 1995; Ercal et al., 2001). In addition to scavenging free radicals, small protein metallothionein (MT) regulate essential metal levels (e.g., $\mathrm{Zn}, \mathrm{Cu}$ ) and detoxify non-essential metals (e.g., Cd, $\mathrm{Hg}$ ) by binding them to their sulfhydryl groups (Kägi, 1991, Isani and Carpenè, 2014).

\footnotetext{
${ }^{*}$ Corresponding author. Institute for Medical Research and Occupational Health, Ksaverska cesta 2, P.O. Box 291, HR-10001, Zagreb, Croatia.

E-mail addresses: mlazarus@imi.hr (M. Lazarus), torct@imi.hr (T. Orct), sergiel@iop.krakow.pl (A. Sergiel), lana.vrankovic@vef.hr (L. Vranković), vfilip@irb.hr (V.F. Marijić), rasic@imi.hr (D. Rašić), sreljic@vef.hr (S. Reljić), jasna.aladrovic@vef.hr (J. Aladrović), tzwijacz@gmail.com (T. Zwijacz-Kozica), fzieba@tpn.pl (F. Zięba), jurasovic@imi.hr (J. Jurasović), erk@irb.hr (M. Erk), robert.maslak@uwr.edu.pl (R. Maślak), nuriselva@gmail.com (N. Selva), djuro.huber@gmail.com (\&. Huber).
} 
Table 1

The biometric data of European brown bears (Ursus arctos) sampled in this study.

\begin{tabular}{|c|c|c|c|c|c|c|c|}
\hline Bear ID & Age & $\operatorname{Sex}^{1}$ & Body mass & Status & Date & Country $^{3}$ & Sample ${ }^{4}$ \\
\hline 1. & 2 & M & 107 & captive & May 2014 & Cro & $\mathrm{B}(\mathrm{p}, \mathrm{s}, \mathrm{wb})$ \\
\hline -resampled & 4 & M & 150 & captive & Nov 2016 & Cro & $\mathrm{B}(\mathrm{p}, \mathrm{s}, \mathrm{wb})+\mathrm{H}$ \\
\hline 2. & 31 & $\mathrm{~F}$ & 116 & captive & Apr2015 & Cro & $\mathrm{B}(\mathrm{p}, \mathrm{s}, \mathrm{wb})+\mathrm{H}$ \\
\hline 3. & 15 & M & 252 & captive & Apr 2015 & Cro & $\mathrm{B}(\mathrm{p}, \mathrm{s}, \mathrm{wb})+\mathrm{H}$ \\
\hline -resampled & 15 & M & 244 & captive & Sep 2015 & Cro & $\mathrm{B}(\mathrm{s})+\mathrm{H}$ \\
\hline 4. & 19 & M & 209 & captive & Jul 2016 & Cro & $\mathrm{B}(\mathrm{p}, \mathrm{s}, \mathrm{wb})$ \\
\hline -resampled & 19 & M & / & captive & Aug 2016 & Cro & $\mathrm{B}(\mathrm{p}, \mathrm{s}, \mathrm{wb})$ \\
\hline 5. & 5 & M & 170 & free-ranging & May 2015 & Cro & $\mathrm{B}(\mathrm{p}, \mathrm{s}, \mathrm{wb})+\mathrm{H}$ \\
\hline 6. & 4 & M & 186 & free-ranging & May 2015 & Cro & $\mathrm{B}(\mathrm{p}, \mathrm{s}, \mathrm{wb})+\mathrm{H}$ \\
\hline 7. & 5 & M & 178 & free-ranging & May 2015 & Cro & $\mathrm{B}(\mathrm{p}, \mathrm{s}, \mathrm{wb})+\mathrm{H}$ \\
\hline 8. & 2 & M & 100 & free-ranging & Jun 2015 & Cro & $\mathrm{B}(\mathrm{p}, \mathrm{s}, \mathrm{wb})+\mathrm{H}$ \\
\hline 9. & 2 & M & 73 & free-ranging & Jun 2015 & Cro & $\mathrm{B}(\mathrm{p}, \mathrm{s}, \mathrm{wb})+\mathrm{H}$ \\
\hline 10. & 2 & $\mathrm{~F}$ & 80 & free-ranging & Oct2015 & Cro & $\mathrm{B}(\mathrm{s}, \mathrm{wb})+\mathrm{H}$ \\
\hline 11. & 1 & $\mathrm{~F}$ & 60 & free-ranging & Oct 2015 & Cro & $\mathrm{B}(\mathrm{p}, \mathrm{s}, \mathrm{wb})$ \\
\hline 12. & 5 & M & 184 & free-ranging & Oct 2015 & Cro & $\mathrm{B}(\mathrm{p}, \mathrm{s})+\mathrm{H}$ \\
\hline 13. & 6 & M & 109 & free-ranging & Apr 2016 & Cro & $\mathrm{B}(\mathrm{p}, \mathrm{s}, \mathrm{wb})+\mathrm{H}$ \\
\hline 14. & 1.5 & M & 39 & free-ranging & May 2016 & Cro & $\mathrm{B}(\mathrm{p}, \mathrm{s}, \mathrm{wb})+\mathrm{H}$ \\
\hline 15. & 8 & M & 176 & free-ranging & May 2016 & Cro & $\mathrm{B}(\mathrm{p}, \mathrm{s}, \mathrm{wb})+\mathrm{H}$ \\
\hline -resampled & 8 & M & 176 & free-ranging & May 2016 & Cro & $\mathrm{B}(\mathrm{p}, \mathrm{s}, \mathrm{wb})$ \\
\hline 16. & 9 & $\mathrm{~F}$ & 101 & free-ranging & May 2016 & Cro & $\mathrm{B}(\mathrm{p}, \mathrm{s}, \mathrm{wb})+\mathrm{H}$ \\
\hline 17. & 0.7 & $\mathrm{~F}$ & 30 & free-ranging & Oct2016 & Cro & $\mathrm{B}(\mathrm{s})$ \\
\hline 18. & 0.7 & $\mathrm{~F}$ & 30 & free-ranging & Oct 2016 & Cro & $\mathrm{B}(\mathrm{s})$ \\
\hline 19. & 3 & M & 210 & free-ranging & May 2017 & Cro & $\mathrm{B}(\mathrm{p}, \mathrm{s}, \mathrm{wb})+\mathrm{H}$ \\
\hline 20. & 7 & $\mathrm{~F}$ & 86 & free-ranging & May 2017 & Cro & $\mathrm{B}(\mathrm{p}, \mathrm{s}, \mathrm{wb})+\mathrm{H}$ \\
\hline 21. & 11 & $\mathrm{~F}$ & 210 & captive & Feb 2011 & Pol & $\mathrm{H}$ \\
\hline 22. & 16 & M & $340^{2}$ & captive & Feb 2011 & Pol & $\mathrm{H}$ \\
\hline -resampled & 21 & M & 350 & captive & Apr 2016 & Pol & $B(s, w b)+H$ \\
\hline 23. & 8 & M & $250^{2}$ & captive & Feb 2011 & Pol & $\mathrm{H}$ \\
\hline 24. & 8 & $\mathrm{~F}$ & $200^{2}$ & captive & Feb 2011 & Pol & $\mathrm{H}$ \\
\hline -resampled & 13 & $\mathrm{~F}$ & 140 & captive & Apr 2016 & Pol & $\mathrm{B}(\mathrm{s}, \mathrm{wb})+\mathrm{H}$ \\
\hline 25. & 36 & $\mathrm{~F}$ & 112 & captive & Feb 2011 & Pol & $\mathrm{H}$ \\
\hline 26. & 16 & M & 260 & captive & Jun 2012 & Pol & $\mathrm{H}$ \\
\hline 27. & 24 & M & 210 & captive & Dec 2014 & Pol & $\mathrm{H}$ \\
\hline 28. & 22 & M & 212 & captive & Jun 2012 & Pol & $\mathrm{H}$ \\
\hline -resampled & 26 & M & $250^{2}$ & captive & Jan 2016 & Pol & $\mathrm{H}$ \\
\hline 29. & 22 & $\mathrm{~F}$ & 145 & captive & Apr 2016 & Pol & $\mathrm{B}(\mathrm{s}, \mathrm{wb})+\mathrm{H}$ \\
\hline 30. & 4 & M & 140 & captive & Apr 2016 & Pol & $\mathrm{B}(\mathrm{s}, \mathrm{wb})+\mathrm{H}$ \\
\hline 31. & 10 & $\mathrm{~F}$ & $100^{2}$ & free-ranging & Oct 2010 & Pol & $\mathrm{H}$ \\
\hline 32. & adult & M & / & free-ranging & Oct 2013 & Pol & $\mathrm{H}$ \\
\hline 33. & 11 & M & 215 & free-ranging & Mar 2014 & Pol & $\mathrm{B}(\mathrm{wb})+\mathrm{H}$ \\
\hline -resampled & 12 & M & 168 & free-ranging & May 2015 & Pol & $\mathrm{B}(\mathrm{s}, \mathrm{wb})+\mathrm{H}$ \\
\hline 34. & adult & M & 205 & free-ranging & Apr 2014 & Pol & $\mathrm{B}(\mathrm{wb})+\mathrm{H}$ \\
\hline 35. & 2 & M & 75 & free-ranging & May 2014 & Pol & $\mathrm{H}$ \\
\hline 36. & 25 & M & 148 & free-ranging & May 2014 & Pol & $\mathrm{B}(\mathrm{s}, \mathrm{wb})+\mathrm{H}$ \\
\hline -resampled & 26 & M & 129 & free-ranging & Jun 2015 & Pol & $\mathrm{B}(\mathrm{s}, \mathrm{wb})$ \\
\hline 37. & 4 & M & 81 & free-ranging & May 2014 & Pol & $\mathrm{B}(\mathrm{s}, \mathrm{wb})$ \\
\hline 38. & 2 & $\mathrm{~F}$ & 92 & free-ranging & Oct 2014 & Pol & $\mathrm{B}(\mathrm{s}, \mathrm{wb})+\mathrm{H}$ \\
\hline 39. & 4 & M & 135 & free-ranging & Nov 2014 & Pol & $\mathrm{B}(\mathrm{s})+\mathrm{H}$ \\
\hline 40. & 17 & $\mathrm{~F}$ & 190 & free-ranging & Mar 2015 & Pol & $\mathrm{B}(\mathrm{s})+\mathrm{H}$ \\
\hline 41. & 1 & M & 35 & free-ranging & Mar 2015 & Pol & $\mathrm{H}$ \\
\hline 42. & 3 & M & 156 & free-ranging & Mar 2015 & Pol & $\mathrm{B}(\mathrm{s})+\mathrm{H}$ \\
\hline 43. & 3 & M & 270 & free-ranging & Apr 2015 & Pol & $\mathrm{B}(\mathrm{s}, \mathrm{wb})+\mathrm{H}$ \\
\hline 44. & 5 & M & 120 & free-ranging & May 2015 & Pol & $\mathrm{B}(\mathrm{s})+\mathrm{H}$ \\
\hline 45. & 5 & $\mathrm{~F}$ & 83 & free-ranging & May 2015 & Pol & $\mathrm{B}(\mathrm{s}, \mathrm{wb})+\mathrm{H}$ \\
\hline 46. & 5 & $\mathrm{~F}$ & 74 & free-ranging & Oct 2015 & Pol & $\mathrm{B}(\mathrm{wb})+\mathrm{H}$ \\
\hline 47. & adult & M & $250^{2}$ & free-ranging & Mar 2016 & Pol & $\mathrm{H}$ \\
\hline 48. & 9 & $\mathrm{~F}$ & 67 & free-ranging & Apr 2016 & Pol & $\mathrm{B}(\mathrm{wb})+\mathrm{H}$ \\
\hline 49. & 1 & $\mathrm{~F}$ & 31 & free-ranging & Apr 2016 & Pol & $\mathrm{H}$ \\
\hline 50. & 18 & $\mathrm{~F}$ & 83 & free-ranging & Apr 2016 & Pol & $\mathrm{B}(w \mathrm{~b})+\mathrm{H}$ \\
\hline 51. & 1 & M & 15 & free-ranging & Apr 2016 & Pol & $\mathrm{B}(w b)+\mathrm{H}$ \\
\hline
\end{tabular}

\footnotetext{
1 M-male, F-female.

2 Estimated body mass.

3 Cro-Croatia, Pol-Poland.

4 B-blood, p-plasma, s-serum, wb-whole blood, H-hair.
}

When elevated, these MT binding metals can induce MTs (Kägi, 1991; Klaassen et al., 1999), and as such, MTs are suitable biomarkers of metal exposure (Gamberg and Scheuhammer, 1994; M'kandawire et al., 2012; Ivanković et al., 2005; Durkalec et al., 2017). Measurement of chemical exposure biomarkers and their effects on apex predators provide valuable information on population health, though such studies are scarce (Rodríguez-Estival and Mateo, 2019).
Brown bear (Ursus arctos) is found in 22 European countries (Chapron et al., 2014), including the Dinaric and Carpathian mountain ranges, as two of the few European habitats hosting three large carnivore species. Brown bear population viability and health is a major focus in wildlife management and has been the aim of conservation efforts in recent decades (Swenson et al., 2000; Kaczensky et al., 2012; Chapron et al., 2014). However, the scarce data available concerning 


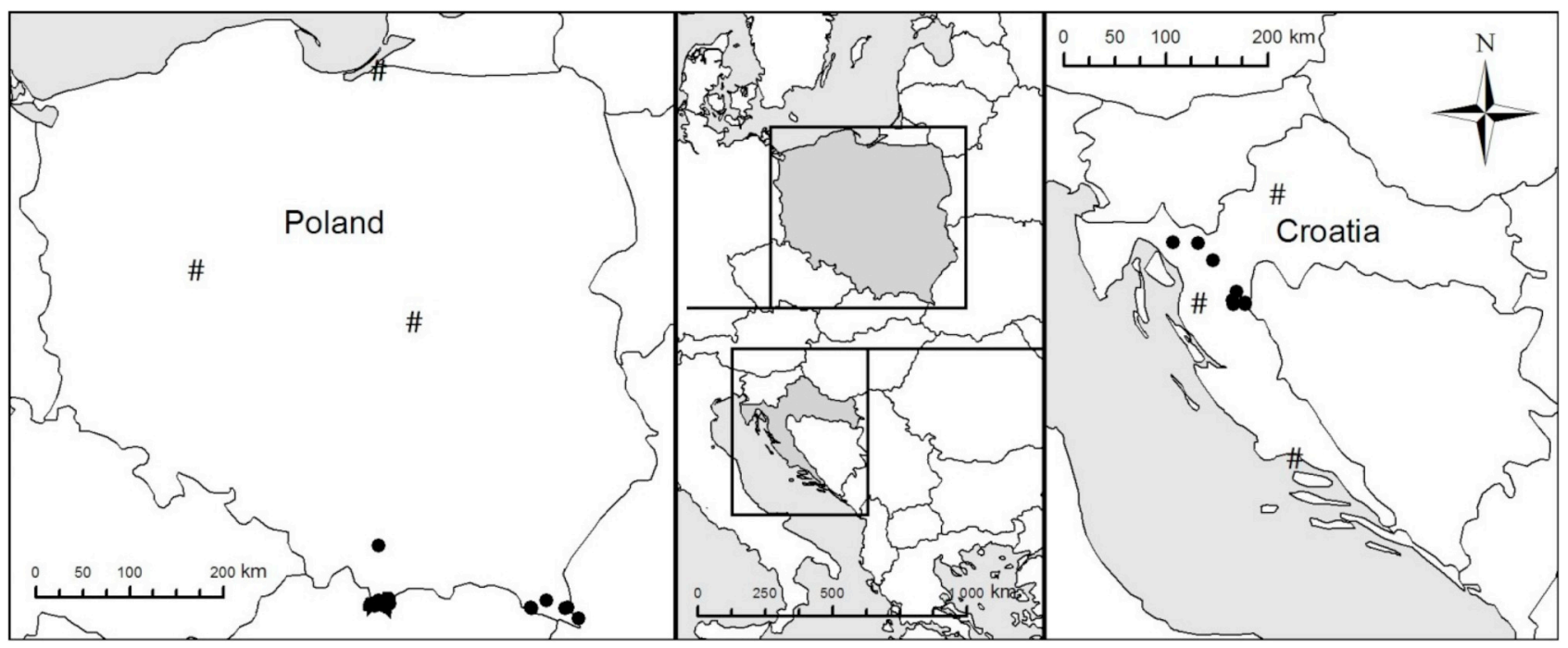

Fig. 1. European brown bear (Ursus arctos) sampling locations: dots indicate free-ranging animals and hash signs indicate captive animals.

environmental toxicant levels in European brown bear populations are based exclusively on dead animal tissue levels of organic (Herceg Romanić et al., 2015) and inorganic contaminants (Medvedev, 1999; Čelechovská et al., 2006; Flaten et al., 2008; Šprem et al., 2016; Lazarus et al. 2017, 2018a, 2018b). Less invasive bioindicator tissues in European brown bears have not been investigated to determine health threats or possible adverse effects. Since brown bears enjoy strict protection status under the Habitats Directive (EC/European Council Directive 92/43/EEC, 1992), non-lethal sampling for scientific purposes has high conservation interest. Blood and hair can be considered a valuable biomonitoring data pool that excludes mortality, and enables longitudinal studies through resampling. Metal(loid)s in blood are a marker of recent exposure, reflecting the net balance of metal(loid) intake (mainly via food), deposition, and excretion. Also, metal(loid)s in blood are bioavailable and thus relevant for toxicological risk assessment. Since there are no bear-specific toxicity benchmarks for nonessential metals in blood, other authors have compared non-European ursid levels with those derived for humans (Rogers et al., 2012; Dietz et al., 2013; Chen et al., 2018). However, human guidelines are highly conservative and of questionable relevance for bears given the known interspecies differences for metal toxicity sensitivity (Dietz et al., 2013), so relevant bear studies on metal-related exposure/effects and risk assessment should be a priority.

Unlike blood, hair can reflect both recent and past exposure in time frames constrained by hair growth and moult. Only during growth, hair takes up elements from circulating blood and binds them to abundant sulfhydryl groups in the cystine of the keratinized shaft, making the elements inert for the host. This accumulative nature of non-essential metals has often been used in hair pollution studies on different nonursid predators (Malvandi et al., 2010; Hernandez-Moreno et al., 2013; Dainowski et al., 2015; Treu et al., 2018), and polar bears (Dietz et al., 2013; Cardona-Marek et al., 2009; Bechshoft et al., 2016) and North American brown bears (Felicetti et al., 2004; Noël et al. 2014, 2015), but there are no data available for the European brown bear. Characterization of hair-to-blood metal relation may help yield useful interpretations of non-essential metal levels in hair, as a minimally invasive sample, to determine the toxicological risk for the individual and population. Although irrefutably connected, the relationships hair-toblood metal levels is highly dependent on species, individual factors (age, foraging behaviour, weaning, growth and moulting status) and ecological factors (e.g., time of year) (Lieske et al., 2011; Peterson et al., 2016).

The aim of this study was to investigate hair and blood (plasma, serum, whole blood) levels of most relevant non-essential metal(loid)s
(As, $\mathrm{Cd}, \mathrm{Hg}, \mathrm{Tl}, \mathrm{Pb}$ ) and their hair-to-blood relation in captive and freeranging European brown bears in order to estimate the possible toxicological risk due to exposure to environmental contaminants, and to assess essential element levels ( $\mathrm{Mg}, \mathrm{Ca}, \mathrm{Mn}, \mathrm{Fe}, \mathrm{Co}, \mathrm{Cu}, \mathrm{Zn}, \mathrm{Se}, \mathrm{Mo}$ ) to examine for possible deficiencies or surpluses. Furthermore, we tested the associations between levels of blood metal(loid)s and biomarkers: biomarker of metal exposure (MT) and biomarkers of effect (antioxidative enzyme activity (SOD, GSH-Px) and oxidative damage to lipids). This study also aimed to set baseline values for the given metal (loid)s in European brown bears and to explore the influence of various confounding individual and ecological factors.

\section{Materials and methods}

\subsection{Animal sampling}

We sampled 51 brown bears from Croatia and Poland in the period 2010-2017, and paired samples of hair and blood (at least one blood component: serum, plasma, whole blood) were collected from 36 individuals (Table 1). Blood was resampled for six bears and hair was resampled for five bears. Altogether, 14 captive (five female, nine males) and 37 free-ranging European brown bear individuals were sampled (14 females, 23 males). In Poland, free-ranging bears were captured for telemetry research and management of problem bears in the Tatra and Bieszczady Mountains in Southern Poland, in the Western and Eastern Carpathians, respectively. Free-ranging bears in Croatia (Dinara-Pindos population) were captured in the Gorski kotar and Lika regions (Fig. 1). Bears are permanently present in both countries, and all sampling areas can be considered pristine without point contamination sources. In compliance with the Habitats Directive, the brown bear is strictly protected in both countries (Selva et al., 2011), though in Croatia it is also listed as a game species within the Directive's derogation provisions, and managed under the Brown Bear Management Plan (Huber et al., 2008). Blood, hair and tooth samples for this study were taken within the framework of research and conservation projects in effect at the time. Captive bears were sampled in zoos and other institutions during regular veterinary checks, interventions or relocations. All bears were chemically immobilized and body measurements were taken (Huber et al., 1996; Kaczensky et al., 2002), and blood was collected from femoral vein in serum and whole blood $\left(\mathrm{K}_{2}\right.$ EDTA coated) tubes). Body mass was measured by suspending the bear from a spring-loaded weigh scale. Serum and plasma were aliquoted into plastic tubes after centrifugation at $3000 \mathrm{rpm}$ for $10 \mathrm{~min}$ and stored with aliquoted whole blood samples at $-20{ }^{\circ} \mathrm{C}$ until 
analysis. Neck or shoulder hair was cut with stainless steel scissors as close to the skin as possible (guard and undercoat hair together) and stored in a paper envelope at room temperature. A premolar tooth was extracted from every free-ranging bear to determine age using the counts of cementum annuli (Matson's Lab, Milltown, Montana, USA; Matson et al., 1993).

\subsection{Element analyses}

Hair was prewashed for $10 \mathrm{~min}$ on a vortex with $20 \mathrm{~mL}$ ultrapure water (18 $\mathrm{M} \Omega \mathrm{cm}$, GenPure system, TKA, Germany) to eliminate soil particles as an external contamination source. The International Atomic Energy Agency (IAEA) recommended 5-step washing procedure was implemented (acetone-water-water-water-acetone; acetone for gas chromatography MS SupraSolv ${ }^{\circledR}$, Merck, Germany), each consisting of a $10 \mathrm{~min}$ vortex with $20 \mathrm{~mL}$ solvent (Ryabukhin, 1976). The hair was then dried for $24 \mathrm{~h}$ at $40^{\circ} \mathrm{C}$, weighted and digested in an UltraCLAVE IV (Milestone, Italy) microwave digestion system. Elements (Mg, Ca, Mn, $\mathrm{Fe}, \mathrm{Co}, \mathrm{Cu}, \mathrm{Zn}, \mathrm{As}, \mathrm{Se}, \mathrm{Mo}, \mathrm{Cd}, \mathrm{Hg}, \mathrm{Tl}, \mathrm{Pb}$ ) in hair were then quantified by inductively coupled plasma mass spectrometry (ICP-MS; Agilent 7500cx, Germany) together with diluted blood (serum, plasma and whole blood) samples according to accepted procedure (Vihnanek Lazarus et al., 2013; Živković et al., 2014). Ultrapure water and purified (duoPUR, Milestone, Italy) nitric acid (p.a. 65\%, Merck, Germany) were used for sample preparation and dilution. The reference material Human hair IAEA-086 (Vienna, Austria), certified reference material (CRM) No.13 Human hair (National Institute for Environmental Studies, Japan), Seronorm ${ }^{\mathrm{TM}}$ Trace Elements Whole blood L-1, L-2 and L-3, Serum L-1 and L-2 (Sero AS, Billingstad, Norway) were processed in duplicate with hair and blood samples to control for the quality of the analytical method. Results of reference material analyses are presented in Table A1 (hair) and Table A2 (blood), with respective method detection limits (MDL) as a supplementary material. Blood element results are expressed in $\mathrm{mg}$ or $\mu \mathrm{g}$ per $\mathrm{L}$ and hair results in $\mathrm{mg}$ or $\mu \mathrm{g}$ per $\mathrm{kg}$ of dry hair mass.

\subsection{Biomarker analyses in serum and whole blood}

The activity of total superoxide-dismutase (SOD; EC 1.15.1.1) and glutathione-peroxidase (GSH-Px; EC 1.11.1.9) was determined by commercial Ransod and Ransel kits (Randox Laboratories, Crumlin, UK), respectively, on a SABA 18 biochemistry analyser (AMS, Rome, Italy). SOD and GSH-Px activity were expressed as units per L of serum/ whole blood.

Metallothionein (MT) was quantified in heat-treated samples by differential pulse voltammetry following a modified Brdička procedure (Raspor et al., 2001) on 797 VA Computrace (Metrohm, Herisau, Switzerland) with a three-electrode system (hanging mercury drop electrode (HMDE), an $\mathrm{Ag} / \mathrm{AgCl} / \mathrm{sat}, \mathrm{KCl}$ reference electrode and a $\mathrm{Pt}$ counter electrode). Measurements were performed in $10 \mathrm{~mL}$ de-aerated supporting electrolyte $(1 \mathrm{M} \mathrm{NH} 4 \mathrm{Cl}+1 \mathrm{M} \mathrm{NH} 4 \mathrm{OH}, \mathrm{pH}=9.5$, $6 \times 10-4 \mathrm{M}[\mathrm{Co}(\mathrm{NH} 3) 6] \mathrm{Cl} 3)$ at constant temperature $\left(20^{\circ} \mathrm{C}\right)$. Serum was diluted twice with $0.9 \% \mathrm{NaCl}$ (suprapur grade, Merck, Darmstadt, Germany), heated at $100{ }^{\circ} \mathrm{C}$ for $15 \mathrm{~min}$ in Techne Dri-Block (Bibby Scientific Limited, Staffordshire, UK), and then cooled on ice for $30 \mathrm{~min}$ prior to centrifugation for $30 \mathrm{~min}$ at $10,000 \mathrm{~g}$ and $4{ }^{\circ} \mathrm{C}$. Metallothionein was quantified in the resulting supernatant using the calibration straight line gained by commercially available $\geq 95 \%$ - pure MT-2 from rabbit liver (Enzo Life Sciences, Inc., NY, USA) dissolved in $0.25 \mathrm{M}$ $\mathrm{NaCl}$, and expressed in mg per $\mathrm{mL}$ of serum.

The malondialdehyde (MDA) as an index of lipid peroxidation was measured using a high-performance liquid chromatography based (HPLC; Shimadzu Corporation, Kyoto, Japan) thiobarbituric acid (TBA) assay (Drury et al., 1997). Within the HPLC apparatus, degasser, isocratic pump, column oven, Shimadzu UV detector set at $532 \mathrm{~nm}, \mathrm{C}-18$ reverse-phase (LiChrospher, Merck, Darmstadt, Germany) guard column and analytical column with $5 \mu \mathrm{m}$ particles $(4.0 \times 4.0$ and $4.0 \times 125.0 \mathrm{~mm}$, respectively) were used. Malondialdehyde content was reported in $\mu$ mol per $L$ of serum.

\subsection{Statistical analyses}

Data below the method detection limit were assigned half of the value of the MDL for the respective metal(loid) for the purpose of statistical analysis. Blood samples collected from the same individual bear twice during the study (i.e. bears $1,3,33$ and 36 , Table 1 ) were considered independent if the period between resampling was longer than 3 months (Rogers et al., 2012). The same period for hair resampling was set at one year which is the time needed for complete hair exchange in bears (Felicetti et al., 2004). Data for bears resampled less than 3 months apart for blood (i.e. bears 4 and 15, Table 1) and 1 year for hair (bear 3) were averaged and used as a single sample in the analysis. The status of bears from Croatia and Poland was either free-ranging or captive (bears kept in zoos or other captive institutions). According to date of sampling, hair was categorized as sampled during growth (May-October) or quiescence (November-April; corrected for southern populations from Cattet et al., 2018). First, each predictor was tested separately by means of a $t$-test for homogenous (Levene's test) and normally distributed (Shapiro-Wilk's test) variables, while the MannWhitney $U$ test was used for heterogeneous and/or non-normally distributed data in blood and hair (Table A3). Spearman rank order correlations $\left(r_{S}\right)$ were used to analyse univariate associations between age and other continuous variables, and interpreted according to Hinkle et al. (2003), where $0.3<\mathrm{r}_{\mathrm{S}} \leq 0.5$ indicated low correlation, $0.5<\mathrm{r}_{\mathrm{S}} \leq 0.7$ moderate correlation, $0.7<\mathrm{r}_{\mathrm{S}} \leq 0.9$ high correlation, and $r_{S}>0.9$ very high correlation. Multivariate linear regression analyses $\left(b, \mathrm{p}\right.$-value, $R^{2}$ ) were then performed to test differences in variables between captive and free-ranging bears taking into account the predictors of age, sex, country and date of sampling (i.e. hair growth phase) in hair. However, given the lower sample number for serum and whole blood variables, multiple analyses of blood included only individual predictors of age and sex while testing if status (captive $v s$. free-ranging) influenced element and biomarker levels. Furthermore, significant predictors from the preceding multivariate model were used in the following model to test for an association between non-essential metals (Cd, Tl and Pb) and biomarkers (MT, MDA, SOD) in blood. Also, blood-hair associations were explored for non-essential metal(loid)s. Residual analyses were performed to check for normality and homoscedasticity, and in cases when those criteria were not met, data were transformed ( $\log _{10}$, inversion, square root; Table A4). The level of significance was set at $\alpha=0.05$. Statistica for Windows software, version 13.0 (StatSoft, Inc., Tulsa, USA) was used in all statistical analyses.

\section{Results}

Bears aged between 0.7 and 31 years weighted between 15 and $350 \mathrm{~kg}$, with captive bears being older (mean 17 years $v s .7$ years old, $\mathrm{t}$ $(52)=4.68, \mathrm{p}<0.001$ ) and heavier than free-ranging bears (mean $205 \mathrm{~kg}$ vs. $121 \mathrm{~kg}, \mathrm{t}(56)=4.50, \mathrm{p}<0.001$ ), on average.

\subsection{Blood}

Brown bear blood as an indicator of recent exposure of the host showed that $\mathrm{Pb}$ is the most relevant non-essential metal(loid), while As and $\mathrm{Hg}$ were mostly below the method detection limit (68-94\% and $74-84 \%$ of all samples, respectively), and $\mathrm{Cd}$ and $\mathrm{Tl}$ had values an order of magnitude lower than $\mathrm{Pb}$ in all compartments (Table 2). Specifically, $\mathrm{Ca}, \mathrm{Co}, \mathrm{Cu}, \mathrm{Mo}$ and $\mathrm{Tl}$ were compartmentalized primarily in serum/ plasma and $\mathrm{Mn}, \mathrm{Fe}, \mathrm{Zn}, \mathrm{Cd}$ and $\mathrm{Pb}$ in whole blood. Activity of GSH-Px in the serum of all bears was below the method detection limit and thus unavailable. For certain variables, the results of multivariate modelling differed from univariate testing (Table A3 vs. Table A4). When bear 
Table 2

Levels of metallothionein, oxidative stress biomarkers and metal(loid)s in European brown bear (Ursus arctos) blood components.

\begin{tabular}{|c|c|c|c|c|c|c|}
\hline & \multicolumn{2}{|c|}{ Serum } & \multicolumn{2}{|c|}{ Plasma } & \multicolumn{2}{|c|}{ Whole blood } \\
\hline & $\mathrm{N}$ & mean $\pm \mathrm{SD}$ (range) median & $\mathrm{N}$ & mean $\pm \mathrm{SD}$ (range) median & $\mathrm{N}$ & mean $\pm \mathrm{SD}$ (range) median \\
\hline MT (mg/mL) & 31 & $1.64 \pm 0.73(0.497-3.67) 1.76$ & & & & \\
\hline MDA $(\mu \mathrm{mol} / \mathrm{L})$ & 35 & $3.86 \pm 2.92(0.846-11.7) 2.83$ & & & & \\
\hline $\mathrm{SOD}(\mathrm{U} / \mathrm{mL})$ & 37 & $1.01 \pm 0.55(0.022-2.33) 0.980$ & & & 35 & $548 \pm 197(264-961) 477$ \\
\hline $\mathrm{Mg}(\mathrm{mg} / \mathrm{L})$ & 37 & $19.3 \pm 2.06(15.5-24.0) 19.2$ & 18 & $19.1 \pm 1.57(15.8-22.1) 19.6$ & 35 & $21.2 \pm 3.11(16.2-28.5) 21.1$ \\
\hline $\mathrm{Ca}(\mathrm{mg} / \mathrm{L})$ & 37 & $91.6 \pm 8.0(69.3-110) 92.4$ & 18 & $110 \pm 6(101-124) 107$ & 35 & $31.5 \pm 6.9(18.8-48.6) 31.2$ \\
\hline $\operatorname{Mn}(\mu \mathrm{g} / \mathrm{L})$ & 37 & $3.47 \pm 1.33(1.69-7.66) 3.26$ & 18 & $2.64 \pm 0.59(1.63-3.64) 2.73$ & 35 & $22.0 \pm 7.4(9.22-34.2) 23.4$ \\
\hline $\mathrm{Fe}(\mathrm{mg} / \mathrm{L})$ & 37 & $6.55 \pm 3.59(0.594-17.6) 6.06$ & 18 & $6.05 \pm 3.28(0.910-12.2) 6.33$ & 35 & $354 \pm 55(195-449) 356$ \\
\hline Co $(\mu \mathrm{g} / \mathrm{L})$ & 37 & $0.771 \pm 0.574(0.130-2.55) 0.670$ & 18 & $0.733 \pm 0.343(0.284-1.43) 0.652$ & 35 & $0.322 \pm 0.271(0.074-1.11) 0.247$ \\
\hline $\mathrm{Cu}(\mathrm{mg} / \mathrm{L})$ & 37 & $0.793 \pm 0.487(0.326-2.34) 0.669$ & 18 & $0.852 \pm 0.433(0.331-1.78) 0.709$ & 35 & $0.473 \pm 0.189(0.225-1.04) 0.390$ \\
\hline $\mathrm{Zn}(\mathrm{mg} / \mathrm{L})$ & 37 & $1.30 \pm 0.27(0.719-1.84) 1.27$ & 18 & $1.26 \pm 0.28(0.703-1.75) 1.23$ & 35 & $2.00 \pm 0.28(1.48-2.66) 1.94$ \\
\hline As $(\mu \mathrm{g} / \mathrm{L})$ & 37 & $(<0.678-2.11)^{1}$ & 18 & $(<0.678-0.881)^{2}$ & 35 & $(<2.37-2.49)^{3}$ \\
\hline Se $(\mu \mathrm{g} / \mathrm{L})$ & 37 & $114 \pm 25(73-207) 110$ & 18 & $81.1 \pm 16(51.0-109) 81.7$ & 35 & $141 \pm 30(80-204) 139$ \\
\hline Mo $(\mu \mathrm{g} / \mathrm{L})$ & 37 & $50.7 \pm 10.8(22.6-71.2) 48.4$ & 18 & $49.8 \pm 11.9(22.2-68.5) 48.2$ & 35 & $13.4 \pm 4.5(3.38-23.3) 13.7$ \\
\hline $\mathrm{Cd}(\mu \mathrm{g} / \mathrm{L})$ & 37 & $0.105 \pm 0.048(<0.070-0.248) 0.101^{4}$ & 18 & $0.106 \pm 0.038(<0.070-0.203) 0.102^{5}$ & 35 & $0.251 \pm 0.234(<0.247-1.21) 0.123^{6}$ \\
\hline $\mathrm{Hg}(\mu \mathrm{g} / \mathrm{L})$ & 37 & $(<0.375-1.11)^{7}$ & 18 & $0.658 \pm 1.847(<0.375-8.47)^{8}$ & 35 & $(<1.31-6.32)^{9}$ \\
\hline $\mathrm{Tl}(\mu \mathrm{g} / \mathrm{L})$ & 37 & $0.049 \pm 0.039(<0.009-0.158) 0.041^{10}$ & 18 & $0.144 \pm 0.105(0.024-0.378) 0.117$ & 35 & $0.063 \pm 0.028(0.032-0.141) 0.053$ \\
\hline $\mathrm{Pb}(\mu \mathrm{g} / \mathrm{L})$ & 37 & $0.944 \pm 0.688(0.147-3.14) 0.691$ & 18 & $3.90 \pm 2.91(0.285-12.0) 4.51$ & 35 & $58.0 \pm 34.7(5.08-168) 49.6$ \\
\hline
\end{tabular}

MT-metallothionein, MDA-malondialdehyde, SOD-superoxide-dismutase, MDL-method detection limit. Elements are listed in order of increasing atomic mass.

$125 / 37<$ As MDL $(0.678 \mu \mathrm{g} / \mathrm{L}$ serum $)$.

2 13/18 < As MDL $(0.678 \mu \mathrm{g} / \mathrm{L}$ plasma $)$

3 33/35 < As MDL $(2.37 \mu \mathrm{g} / \mathrm{L}$ blood $)$.

4 5/37 < Cd MDL $(0.070 \mu \mathrm{g} / \mathrm{L}$ serum $)$.

$52 / 18<\mathrm{Cd}$ MDL $(0.070 \mu \mathrm{g} / \mathrm{L}$ plasma $)$.

6 22/35 < Cd MDL $(0.247 \mu \mathrm{g} / \mathrm{L}$ blood $)$.

7 31/37 < Hg MDL $(0.375 \mu \mathrm{g} / \mathrm{L}$ serum $)$.

8 15/18 < Hg MDL (0.375 $\mu \mathrm{g} / \mathrm{L}$ plasma).

9 26/35 < Hg MDL (1.31 $\mu \mathrm{g} / \mathrm{L}$ blood).

$103 / 37<\mathrm{Tl}$ MDL $(0.009 \mu \mathrm{g} / \mathrm{L}$ serum $)$.

status was analysed while controlling for age and sex, free-ranging animals showed higher activity of SOD in whole blood $(b=0.40$, $\left.\mathrm{p}=0.04, R^{2}=0.18\right)$, serum and whole blood $\mathrm{Mn}(b=0.54, \mathrm{p}=0.01$, $R^{2}=0.35$ and $b=0.44, \mathrm{p}=0.01, R^{2}=0.35$, respectively), $\mathrm{Zn}$ $\left(b=0.46, \mathrm{p}=0.05, R^{2}=0.13\right)$ and $\mathrm{Cd}(b=0.54, \mathrm{p}=0.02$, $\left.R^{2}=0.24\right)$ than captive animals, while the opposite was true for serum $\operatorname{Mg}\left(b=-0.49, \mathrm{p}=0.02, R^{2}=0.26\right.$; Table A4). However, relatively small biomarker/element variation in the blood compartments (13-35\%; Table A4) could be attributed to the influence of age, sex and captivity status of bears. Older animals had lower SOD in serum $(b=-0.45, \mathrm{p}=0.01)$, Co $(b=-0.48, \mathrm{p}=0.03$ and $b=-0.49$, $\mathrm{p}=0.009)$ and Mo $(b=-0.50, \mathrm{p}=0.02$ and $b=-0.65, \mathrm{p}<0.001)$ in serum and whole blood, respectively (Table A4). Unlike whole blood $\mathrm{Cu}$ levels $(b=-0.37, \mathrm{p}=0.03)$, females had higher serum SOD activity $(b=0.35, \mathrm{p}=0.02), \mathrm{Mg}(b=0.38, \mathrm{p}=0.03)$ and $\mathrm{Mn}(b=0.32$, $\mathrm{p}=0.04)$ and whole blood $\mathrm{Mn}(b=0.38, \mathrm{p}=0.02)$ and Se $(b=0.34$, $\mathrm{p}=0.05$ ) levels than males (Table A4). When the association between non-essential metals and biomarkers was explored controlling for significant predictors, serum $\mathrm{Pb}$ revealed a significant correlation with SOD activity in whole blood $\left(b=0.47, \mathrm{p}=0.04, R^{2}=0.19\right.$; Table A5, Fig. 3). Data for serum and whole blood categorized by captivity status of bears are presented in Table A6; however, plasma was omitted from the table due to the low sample number. According to univariate analyses, bears sampled in Croatia showed higher SOD activity, levels of $\mathrm{Co}, \mathrm{Cu}$ and Mo compared to bears from Poland, while the opposite was evident for $\mathrm{Mn}$ and $\mathrm{Zn}$ in the blood (Table A3). Seasonal variation in non-essential metal(loid)s (only $\mathrm{Cd}$ and $\mathrm{Pb}$ analysed, as $\mathrm{Hg}$ and As were mostly below the MDL) displayed in Fig. 2A and C indicated two seasonal peaks in whole blood $\mathrm{Cd}$ and $\mathrm{Pb}$ in April-May and October corresponding to emergence from the den/extensive feeding compared to winter period, and prior to denning/end of hyperphagic period, respectively. The correlation matrix between $\mathrm{Pb}$, as the most abundant non-essential metal, and essential metals in blood compartments revealed a low association of $\mathrm{Pb}$ with $\mathrm{Mn}\left(\mathrm{N}=35, \mathrm{r}_{\mathrm{S}}=0.39, \mathrm{p}=0.02\right)$,
Zn $\left(\mathrm{N}=35, \mathrm{r}_{\mathrm{S}}=0.36, \mathrm{p}=0.03\right)$ and $\mathrm{Mo}\left(\mathrm{N}=35, \mathrm{r}_{\mathrm{S}}=-0.35\right.$, $\mathrm{p}=0.04)$.

\subsection{Hair}

In general, essential elements in hair had a similar distribution as in the blood compartments, except for Zn and Se (Table 3). Zn was much more abundant in hair than in blood, while Se was the lowest of all essential elements in hair, but the most abundant element ( $\mathrm{Ca}$ and $\mathrm{Fe}$ in whole blood) in serum and plasma. In addition, the majority of elements with blood values below the MDL (mostly non-essential ones) were quantified in a higher percentage in hair samples. Results of multivariate linear regression revealed captivity status as an important predictor for $\mathrm{Mg}\left(b=-0.53, \mathrm{p}=0.008, R^{2}=0.17\right)$, $\mathrm{Ca}(b=-0.87$, $\left.\mathrm{p}<0.001, R^{2}=0.56\right)$, Co $\left(b=0.33, \mathrm{p}=0.007, R^{2}=0.69\right), \mathrm{Cd}$ $\left(b=0.53, \mathrm{p}<0.001, R^{2}=0.59\right), \mathrm{Tl}\left(b=0.34, \mathrm{p}=0.01, R^{2}=0.66\right)$ and $\mathrm{Pb}$ levels $\left(b=0.39, \mathrm{p}=0.02, R^{2}=0.45\right)$ explaining up to $69 \%$ of element variation, while controlling for age, sex, country and hair growth phase. Free-ranging bears had higher $\mathrm{Co}, \mathrm{Cd}, \mathrm{Tl}$ and $\mathrm{Pb}$ and lower $\mathrm{Mg}$ and $\mathrm{Ca}$ levels than captive ones. The other four predictors were not significant in this model, except age for $\mathrm{Mn}(b=-0.35$, $\mathrm{p}=0.02)$, Fe $(b=-0.37, \mathrm{p}=0.006)$ and Co $(b=-0.25, \mathrm{p}=0.04)$, country for Co $(b=-0.21, \mathrm{p}=0.04)$, Mo $(b=-0.41, \mathrm{p}=0.01)$ and $\mathrm{Tl}(b=-0.48, \mathrm{p}<0.001)$, and hair growth phase for Fe $(b=-0.32$, $\mathrm{p}=0.01)$ and Co $(b=-0.25, \mathrm{p}=0.02$; Table A.4). Regression analyses of blood-to-hair non-essential metal levels with status and/or country as confounding factors revealed no significant relationship between the two matrices (Table A7).

\section{Discussion}

This study examined blood as a non-lethal indicator of recent exposure and hair as a blood-related tissue, depicting medium exposure history. All three blood components were investigated to enable future 
A)

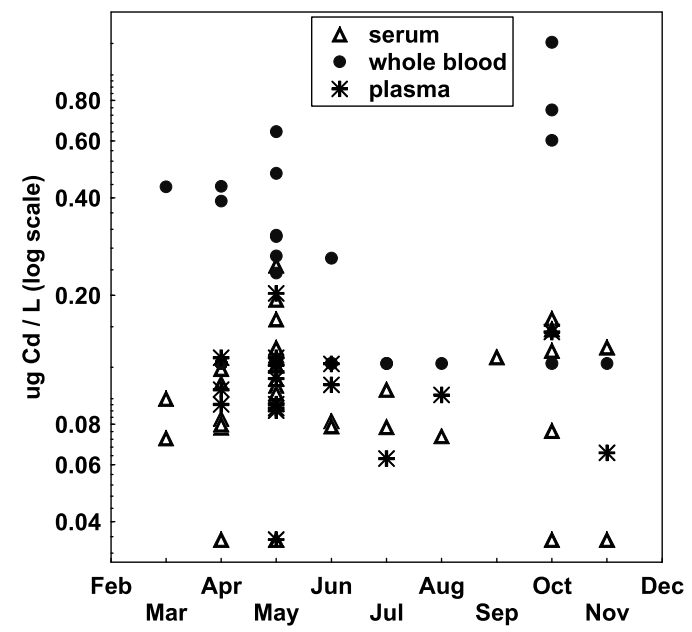

C)

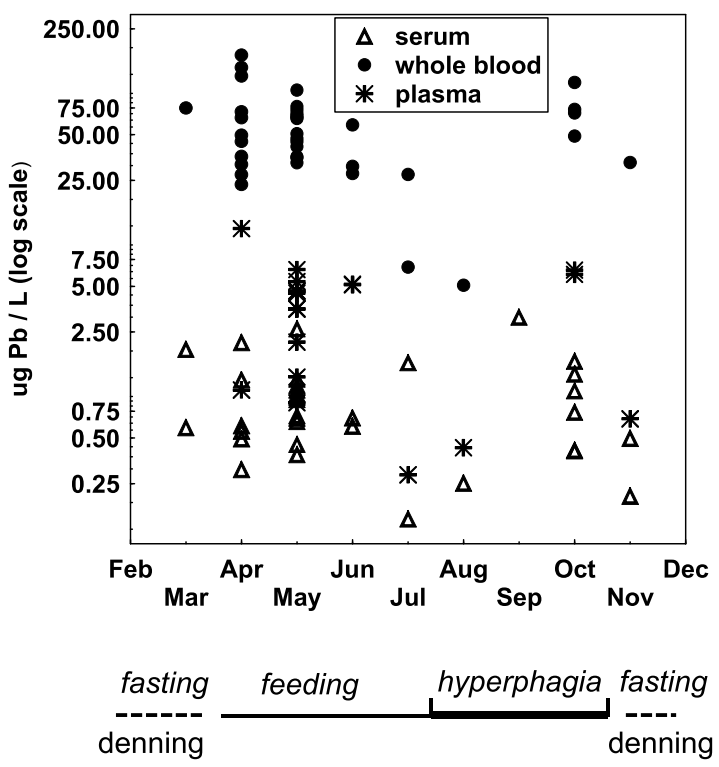

B) HAIR

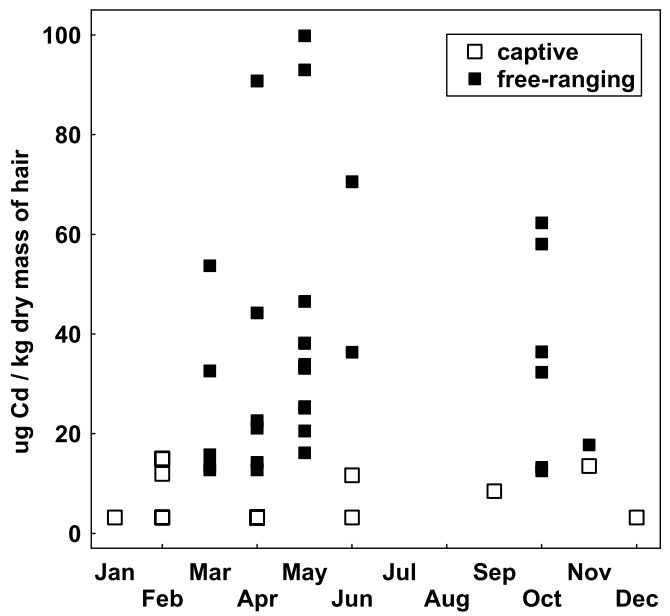

D)
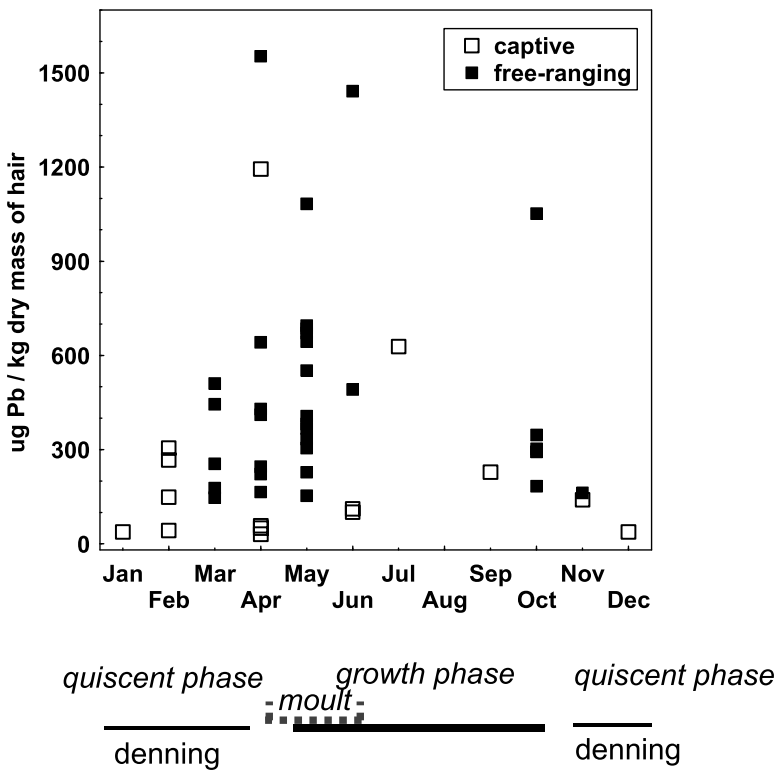

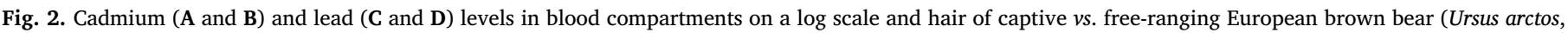
individual values) by sampling month.

between-studies comparisons and correlation of measured metal(loid) levels with biomarkers of exposure and effect. The obtained baseline data will enable future assessment of toxicological risk related to metal (loid) toxicity or deficiency (defined in whole blood or plasma/serum, depending on the element) in the Dinara-Pindos and Carpathian populations, or in any of the 10 European brown bear populations (Chapron et al. 2014).

\subsection{Blood}

Differential metal(loid) compartmentalization in the blood addresses the need for both whole blood and serum/plasma sampling in monitoring studies. As serum and plasma metal(loid) levels were similar for most elements, future studies should focus on plasma sampling to rationalize multiple tube handling and the amount of drawn blood and avoid coagulation-related changes in measured biomarkers of lipid peroxidation.

Lead was the most abundant non-essential metal measured in brown bear blood (Table 2), known as a critical target of $\mathrm{Pb}$ toxicity (Matović et al. 2015). The presence of $\mathrm{Fe}$ and $\mathrm{Pb}$ (>1\%, Matović et al. 2015) in the serum/plasma of some individuals indicated various grades of haemolysis, as both elements are characteristic for erythrocytes. Erythrocytes are a dominant blood subcompartment repository for $\mathrm{Pb}$, although more slowly exchangeable than plasma. Except recent exposure, $\mathrm{Pb}$ in human whole blood $(\mathrm{PbB})$ also reflects past exposure due to mobilization of $\mathrm{Pb}$ from bone during remodelling (Barbosa et al. 2005). Mean (median) $\mathrm{PbB}$ levels in free-ranging (61.2 (64.0) $\mu \mathrm{g} / \mathrm{L}$ ) and captive (49.2 (29.6) $\mu \mathrm{g} / \mathrm{L}$ ) brown bears from Croatia and Poland (Table A6) were similar to those in North American brown bears (median, $44 \mu \mathrm{g}$ / $\mathrm{L}$ ), but higher than in black bears (median, $16 \mu \mathrm{g} / \mathrm{L}$ ) from the greater Yellowstone ecosystem, USA (Rogers et al. 2012) and captive giant panda from Longuantai, China (mean $181 \mu \mathrm{g} / \mathrm{L}$, recalculated by multiplying $0.171 \mu \mathrm{g} / \mathrm{g}$ with blood density of $1060 \mathrm{~g} / \mathrm{L}$, Chen et al. 2018). Blood $\mathrm{Pb}$ in captive giant pandas was higher than in free-ranging animals (Chen et al. 2018), which was contrary to the results in Croatian and Polish captive bears which had a median $\mathrm{PbB}$ half that of freeranging brown bears (Table A6), although multivariate analysis declined significance of status for PbB levels (Table A4). Higher exposure to $\mathrm{Pb}$ in captive animals was expected given the urbanised zoo locations (Travis et al. 2012); however, it appears that for brown bears, food 


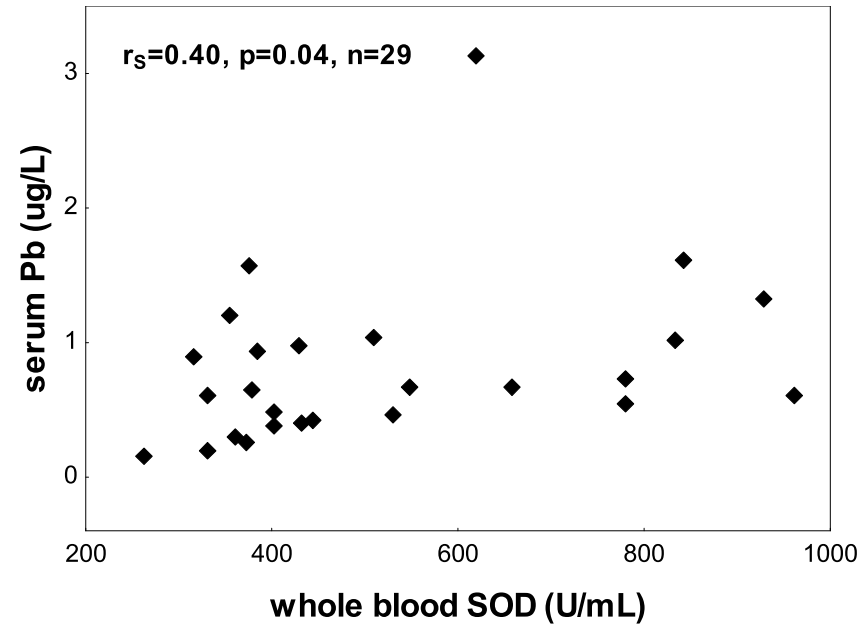

Fig. 3. Relationship between whole blood superoxide-dismutase (SOD) activity (x-axis) and lead level (y-axis) in the serum of European brown bear (Ursus arctos). Spearman's correlation coefficient $\left(\mathrm{r}_{\mathrm{S}}\right)$ with the level of significance indicates the degree of relation between the variables.

origin plays a crucial role in deriving differences. Food given to bears in captive institutions across Croatia and Poland is primarily produced and intended for human consumption (e.g., bread, corn, fruits, vegetables) and the diet is fairly uniform year round, and therefore high $\mathrm{Pb}$ is not expected. On the contrary, free-ranging bears have seasonal variation in food availability, especially in spring, when the majority of animals were sampled in this study and when they rely on leafy plants (Cicnjak et al. 1987; Kusak and Huber 1998) which are most vulnerable to airborne $\mathrm{Pb}$ atmospheric deposition (ATSDR 2019). Atmospheric $\mathrm{Pb}$ deposition is known to increase with altitude (ATSDR 2019), and therefore, this might have also influenced the higher $\mathrm{Pb}$ level in freeranging bears inhabiting the mountainous areas of Croatia and Poland. Another possible source of $\mathrm{Pb}$ for wildlife scavengers are bullet fragments left in the carcasses of hunted animals (Taggart et al. 2011; Martin et al. 2019). Although this source of $\mathrm{Pb}$ was confirmed in cougar (Puma concolor, Burco et al. 2012), but not for bears (Rogers et al. 2012), we suspect brown bears might be exposed to $\mathrm{Pb}$ from ammunition while scavenging on hunted wild ungulates as a minor component of the bear diet (Cicnjak et al. 1987; Kusak and Huber 1998; Ważna et al. 2017; Bojarska 2015). Given the lack of a relevant effect threshold $\mathrm{PbB}$ levels for wildlife species, other authors have assessed the possibility of estimating the adverse effects in wildlife using data based on humans (ATSDR 2019; Ettinger et al. 2019), domestic animals (Puls 1994) or thresholds derived from various mammalian toxicity studies (Buekers et al. 2009). Fifteen individuals (43\%, N = 35) in this study had $\mathrm{PbB}$ above $60 \mu \mathrm{g} / \mathrm{L}$, considered the background level for cattle (Ma, 2011). Rodriguez-Estival et al. (2012 and references cited therein) found decreased activity of an enzyme involved in haeme biosynthesis, $\delta$-aminolevulinic acid dehydratase ( $\delta$-ALAD), in cattle even at the background $\mathrm{PbB}$ level range $(60 \mu \mathrm{g} / \mathrm{L})$, while oxidative stress, an imbalance in essential elements and interferences of $\mathrm{Pb}$ with metabolism of vitamin $\mathrm{D}$ were reported in $\mathrm{PbBs}$ ranging from 60 to $350 \mu \mathrm{g} / \mathrm{L}$. In this study, a positive relationship was found between serum $\mathrm{Pb}$ and SOD activity in whole blood (Fig. 3), although $57 \%$ of individuals had $\mathrm{PbB}$ within the background range $(<60 \mu \mathrm{g} / \mathrm{L}$, Ma 2011). This elevation in enzyme activity could be an adaptive mechanism of the enzyme to low $\mathrm{Pb}$ exposure (hormesis) as a consequence of higher production of reactive oxygen species (Flora et al. 2012). In addition, the highest $\mathrm{PbB}$ level $(168 \mu \mathrm{g} / \mathrm{L})$ measured in a male captive bear, was still below the currently considered threshold for infertility and foetal abnormalities in mammals ( $>200 \mu \mathrm{g} / \mathrm{L}$, Ma 2011). Three adult and one yearling (1 year old) brown bear surpassed the adult human threshold for $\mathrm{PbB}$, above which a decreased activity of several haeme biosynthesis enzymes and elevated blood pressure was reported (100 $\mu \mathrm{g} / \mathrm{L}$, ATSDR 2019).

Cadmium was the second highest non-essential metal measured in the blood of brown bears (Table 2). Absorbed from the intestines, cadmium is known to bind erythrocyte membranes, protein albumin and MT in the blood (Matović et al. 2015). Croatian and Polish brown bears showed the lowest blood Cd levels among ursids. Other studies reported a tenfold higher Cd mean $(2.54 \mu \mathrm{g} / \mathrm{L}$, recalculated from Chen et al. 2018) in whole blood of captive giant panda and a 100-fold higher level in polar bears in East Greenland (plasma mean, $16.4 \mu \mathrm{g} / \mathrm{L}$; range, $0.034-181 \mu \mathrm{g} / \mathrm{L}$, recalculated using the density of plasma of $1025 \mathrm{~g} / \mathrm{L}$; Uba 2013) than in bears from this study (mean plasma, $0.106 \mu \mathrm{g} / \mathrm{L}$; whole blood, $0.251 \mu \mathrm{g} / \mathrm{L}$ ). The cause for such a difference is not clear and may ensue from dietary differences, i.e., exposure rates or interspecies differences in $\mathrm{Cd}$ metabolism. Whatever influenced such

Table 3

Level of metal(loid)s in hair of free-ranging and captive European brown bear (Ursus arctos).

\begin{tabular}{|c|c|c|c|}
\hline & All $(\mathrm{N}=50)$ & Free-ranging $(\mathrm{N}=34)$ & Captive $(\mathrm{N}=16)$ \\
\hline & \multicolumn{3}{|l|}{ mean $\pm \mathrm{SD}$ (range) median } \\
\hline $\mathrm{Mg}(\mathrm{mg} / \mathrm{kg})$ & $121 \pm 72(24.6-317) 116$ & $104 \pm 57(24.6-213) 104$ & $156 \pm 86(31.4-317) 145$ \\
\hline $\mathrm{Ca}(\mathrm{mg} / \mathrm{kg})$ & $940 \pm 733(224-3757) 694$ & $595 \pm 345(224-1764) 524$ & $1629 \pm 823(397-3757) 1548$ \\
\hline Mn (mg/kg) & $10.3 \pm 8.9(0.487-38.2) 7.86$ & $13.0 \pm 9.4(2.42-38.2) 9.70$ & $4.52 \pm 3.42(0.487-10.3) 3.71$ \\
\hline $\mathrm{Fe}(\mathrm{mg} / \mathrm{kg})$ & $69.3 \pm 64.7(7.90-289) 57.1$ & $86.9 \pm 57.6(13.9-270) 74.0$ & $37.1 \pm 66.1(7.90-289) 17.5$ \\
\hline Co $(\mu \mathrm{g} / \mathrm{kg})$ & $67.3 \pm 70.9(<8.14-300) 39.8^{1}$ & $92.1 \pm 74.7(<8.14-300) 70.8$ & $17.7 \pm 17.3(<8.14-51.4) 9.23$ \\
\hline $\mathrm{Cu}(\mathrm{mg} / \mathrm{kg})$ & $10.0 \pm 2.1(6.30-15.5) 9.77$ & $10.1 \pm 2.36(6.30-15.5) 9.71$ & $9.79 \pm 1.63(6.52-12.9) 9.90$ \\
\hline $\mathrm{Zn}(\mathrm{mg} / \mathrm{kg})$ & $140 \pm 13(112-177) 140$ & $143 \pm 12(124-177) 142$ & $134 \pm 14(112-161) 130$ \\
\hline As $(\mu \mathrm{g} / \mathrm{kg})$ & $95.3 \pm 102.8(<22.4-404) 60.7^{2}$ & $119 \pm 114(32.9-404) 70.9$ & $47.7 \pm 49.8(<22.4-187) 28.8$ \\
\hline $\mathrm{Se}(\mathrm{mg} / \mathrm{kg})$ & $0.489 \pm 0.167(0.238-1.00) 0.446$ & $0.476 \pm 0.167(0.238-1.00) 0.432$ & $0.517 \pm 0.168(0.312-1.00) 0.461$ \\
\hline Mo $(\mu \mathrm{g} / \mathrm{kg})$ & $71.8 \pm 45.0(<12.0-258) 61.7^{3}$ & $71.7 \pm 49.3(<12.0-258) 59.4$ & $71.9 \pm 34.8(20.3-140) 67.2$ \\
\hline $\mathrm{Cd}(\mu \mathrm{g} / \mathrm{kg})$ & $26.8 \pm 24.6(<6.37-99.8) 16.9^{4}$ & $36.8 \pm 24.3(12.5-99.8) 32.8$ & $6.71 \pm 4.92(<6.37-15.0) 3.18$ \\
\hline $\mathrm{Hg}(\mu \mathrm{g} / \mathrm{kg})$ & $128 \pm 128(<43.0-562) 91.8^{5}$ & $156 \pm 143(<43.0-562) 102$ & $74.2 \pm 66.5(<43.0-192) 21.5$ \\
\hline $\mathrm{Tl}(\mu \mathrm{g} / \mathrm{kg})$ & $3.99 \pm 2.80(<0.6-12.5) 3.72^{6}$ & $4.98 \pm 2.84(0.852-12.5) 4.15$ & $2.18 \pm 1.58(<0.6-5.35) 1.86$ \\
\hline $\mathrm{Pb}(\mu \mathrm{g} / \mathrm{kg})$ & $401 \pm 354(30.3-1553) 302$ & $479 \pm 348(147-1553) 374$ & $225 \pm 311(30.3-1194) 112$ \\
\hline
\end{tabular}

Elements are listed in order of increasing atomic mass

$19 / 50<$ Co MDL $(8.14 \mu \mathrm{g} / \mathrm{kg})$.

$26 / 50<$ As MDL $(22.4 \mu \mathrm{g} / \mathrm{kg})$.

$31 / 50<$ Mo MDL $(12.0 \mu \mathrm{g} / \mathrm{kg})$.

$410 / 50<$ Cd MDL $(6.37 \mu \mathrm{g} / \mathrm{kg})$.

$514 / 50<\mathrm{Hg}$ MDL $(43.0 \mu \mathrm{g} / \mathrm{kg})$.

6 1/50< Tl MDL $(0.6 \mu \mathrm{g} / \mathrm{kg})$. 
variation between species in blood as a marker of recent assimilation of Cd (ATSDR 2012), the resulting accumulation in target organs (kidney and liver, 20.3 and $1.77 \mu \mathrm{g} / \mathrm{g}$ wet weight, respectively in polar bear, Uba 2013 vs. 19.4 and $1.26 \mu \mathrm{g} / \mathrm{g}$ wet weight, respectively in brown bear, Lazarus et al. 2017) indicate a similar long-term exposure. The highest measured whole blood value $(1.21 \mu \mathrm{g} / \mathrm{L})$ in brown bears was well below toxic thresholds for large domestic animals (Puls 1994), used for comparison due to the lack of appropriate wildlife thresholds. Furthermore, no association was found between $\mathrm{Cd}$ in blood and biomarkers of exposure (MT) or oxidative stress (SOD, MDA) in the studied individuals (Table A5). The lack of a Cd-MT relation could be due to low Cd levels in bear blood that are too low to induce MT synthesis, as reported for marine mammals (Polizzi et al. 2017). Adam et al. (2007) found that the MT level depended on trophic levels of the species, thus carnivorous animals had higher MT levels in blood than herbivores. In this study, MT was quantified for the first time in some ursid species. Dietary differences and consequently $\mathrm{Cd}$ exposure resulted in higher serum (mean, $0.120 \mu \mathrm{g} / \mathrm{L}$ ), plasma $(0.122 \mu \mathrm{g} / \mathrm{L})$ and whole blood $\mathrm{Cd}$ levels $(0.298 \mu \mathrm{g} / \mathrm{L})$ in free-living bears (Table A6) compared to captive ones $(0.073,0.076$ and $0.123 \mu \mathrm{g} / \mathrm{L}$, respectively), though the difference was statistically significant only for serum (multivariate analyses, Table A4). Cd-rich viscera of domestic and especially wild ungulate animals (Lazarus et al. 2008; Taggart et al. 2011) left in the woods can increase the intake of Cd for free-living bears compared to captive ones. However, it should be noted that food of animal origin accounts for only a minor part of the bear's diet, with preference on plant-based foods (Cicnjak et al. 1987; Kusak and Huber 1998; Ważna et al. 2017; Bojarska 2015). Other non-essential metal(loid)s, like As and $\mathrm{Hg}$ were detected in $6-32 \%$ and $16-26 \%$ of brown bear samples (Table 2), respectively, and at an order of magnitude lower than reported for Florida black bears (Ursus americanus floridanus, whole blood $\mathrm{Hg}$ mean, $53 \mu \mathrm{g}$ / $\mathrm{L}$, recalculated from Julian and Cunningham 2013), captive giant pandas (whole blood mean, As $25.5 \mu \mathrm{g} / \mathrm{L}$, recalculated from Chen et al. 2018) or polar bears (plasma mean, As $37.2 \mu \mathrm{g} / \mathrm{L}$ and $\mathrm{Hg} 57.5 \mu \mathrm{g} / \mathrm{L}$, Uba 2013; whole blood mean, $\mathrm{Hg} 74.2 \mu \mathrm{g} / \mathrm{L}$, Cardona-Marek et al. 2009). The highest Hg levels measured in blood were $739 \mu \mathrm{g} / \mathrm{L}$ in polar bear (reviewed in Dietz et al. 2013), which is known to be affected by higher $\mathrm{Hg}$ bioaccumulation and biomagnification given its marine diet (Scheuhammer et al. 2015), as opposed to the brown bears and Florida black bears which are exclusively part of the terrestrial food web. Thus, the Hg difference in bears from this study and in Florida black bears suggest geographical differences, as their diets are very similar (Murphy et al. 2017; Cicnjak et al. 1987; Kusak and Huber 1998). In this study, all brown bears had blood $\mathrm{Hg}$ within the normal range established for cattle, sheep ( $<106 \mu \mathrm{g} / \mathrm{L}$, Puls 1994) and humans ( $<20 \mu \mathrm{g} / \mathrm{L}$, Klaassen et al. 2013), as no wildlife threshold is available. Thallium was present in the blood of brown bears at much lower levels than non-essential metals such as $\mathrm{Cd}, \mathrm{Pb}$, or $\mathrm{Hg}$, though its toxicity is much higher (Peter and Viraraghavan 2005). The blood Tl (Table 2) reported here can be considered normal according to CDC human guidelines $(<2 \mu \mathrm{g} / \mathrm{L})$, given the lack of wildlife data.

According to mammalian and human thresholds and guidelines for non-essential metal(loid)s, only the $\mathrm{Pb}$ levels in brown bear blood compartments raised concern regarding possible adverse health effects. Due to the chemical and physical resemblance, the interaction of $\mathrm{Pb}$ with essential elements ( $\mathrm{Na}, \mathrm{Mg}, \mathrm{Ca}, \mathrm{Fe}, \mathrm{Cu}, \mathrm{Zn}$ ) can cause their deficiency, or affect enzyme activity and function of cells and organs (Telišman 1995; Goyer 1997; Flora et al. 2012). Associations of Pb with $\mathrm{Mn}$ and $\mathrm{Zn}$ found in brown bear might indicate a replacement of $\mathrm{Pb}$ with essential elements in $\delta$-ALAD and SOD or shared binding sites on transporters in intestinal cells (Telišman 1995; Goyer 1997; Peraza et al. 1998). The adverse relations between $\mathrm{Pb}$ and Mo might be connected to the well-defined $\mathrm{Cu}-\mathrm{Mo}$ interaction, as $\mathrm{Pb}$ was reported to reduce Cu storage in sheep (Puls 1994). However, essential elements in brown bear fitted the adequate ranges defined for domestic animals (Puls 1994), as relevant data for wild large mammals does not exist in the literature, and therefore, we can propose that no excess or deficiency is expected in our bears.

\subsection{Hair}

For this study, guard and underfur hair was sampled to assess the baseline element levels over a larger period of time and to promote the use of snagged hair in future research as the most easily available hair sample. Lead was the most abundant non-essential metal in the hair of brown bears, followed by $\mathrm{Hg}$, As $\mathrm{Cd}$ and $\mathrm{Tl}$. All non-essential metal (loid)s except As were much lower in hair than in liver and kidney of the Croatian bear population (recalculated to dry mass from Lazarus et al. 2017), confirming those two organs are more important storage sites than hair, taking into account the medium exposure window reflected by hair.

Bearing in mind the differences in age and sex distribution, other ursids had higher Hg (North American brown bear, Noël et al. 2014; Florida black bear, Julian and Cunningham 2013; polar bear, Uba 2013, Dietz et al., 2013) and Cd (Uba 2013), similar Se and Zn (Uba 2013), but lower Pb and As (Uba 2013) hair levels than the bears in our study. Hair $\mathrm{Hg}$ levels were similar in female but higher in male North American brown bears from Yellowstone than in brown bears in this study (Felicetti et al. 2004). The mean level of $\mathrm{Hg}$ detected in brown bears from Croatia and Poland $(128 \mu \mathrm{g} / \mathrm{kg})$ was 40 times lower than the neurotoxic threshold suggested for $\mathrm{Hg}$ in polar bear $(5400 \mu \mathrm{g} / \mathrm{kg}$ dry mass, Dietz et al. 2013) so adverse health effects are not expected. Other hair non-essential metal(loid)s were in the range considered normal for domestic animals (Puls 1994). Also, due to a lack of data for wild large mammals, essential elements in bear hair were compared and seen to fit the ranges regarded as adequate for domestic mammals (Puls 1994).

The absence of age-related differences in brown bear hair $\mathrm{Hg}$ was in line with the report of Cardona-Marek et al. (2009) for Southern Beaufort Sea polar bear, but less than in Western Hudson Bay polar bear (Bechshoft et al. 2016). In contrast to brown bears in this study, Hernandez-Moreno et al. (2013) reported higher hair Pb in adult Iberian wolves than in young individuals. Cardona-Marek et al. (2009) reported higher $\mathrm{Hg}$ in the hair of female polar bears, while metal(loid)s in bears from this study failed to differentiate between the sexes, as seen also for the Iberian wolf (Hernandez-Moreno et al. 2013). Free-ranging brown bears had enhanced hair non-essential metal(loid)s level with more pronounced fluctuations compared to captive bears (Tables 3, A4). As for blood, the lower exposure of captive bears through humanintended food can be assumed to cause this difference. Also, metal content in hair plotted against sampled months reflected the uniformity of the captive bear diet throughout the year, especially for Cd levels (Fig. 2). Noël et al. (2014, 2015) confirmed hair Hg, Cu and Zn, but not $\mathrm{Pb}, \mathrm{Cd}$ and $\mathrm{Fe}$ as good indicators of grizzly bear dietary changes. However, in addition to seasonal changes in the diet of free-ranging bears, the seasonal cycle of hair also complicates interpretation of element levels found in bear hair. In general, brown bear hair in the two studied populations grows (and takes up elements from the blood) from May to October (Cattet et al. 2018, corrected for southern populations), i.e., in the period of non-hibernation and good food availability. Moulting occurs between April and June, so hair sampled after June and before hibernation will contain only elements taken up to newly grown hair in that period. Also, hair cycle phases in captive bears differ from free-ranging bears, because of the shorter hibernation and higher food availability (Cattet et al. 2018). Thus, hair physiology might also have an effect on metal(loid)s in captive $v s$. free-ranging populations, though no differences were seen in non-essential metal(loid)s between the two periods (Table A4). However, the peaks observed in hair Cd and $\mathrm{Pb}$ levels sampled in May and October can be considered to mostly reflect enhanced dietary exposure in spring and hyperphagia in fall, as a similar pattern was also confirmed in blood (Fig. 2). Nonetheless, for firmer conclusions, future studies should include a larger sample. 
While investigating non-essential metal associations between two matrices (blood and hair) of brown bear, it was found that metals in one matrix were not predictive of levels in the other (Table A7). One of the reasons could be the sampling timing. Hair reflects blood levels best when: i) new hair is sampled; ii) hair is in its growth phase (after moulting); iii) exposure is relatively constant (Peterson et al. 2016). The bears in this study were sampled opportunistically throughout the year (except hibernation), and diet exposure had seasonal variations, and accordingly some bears may have been impacted by a fasting period marked with element mobilization into the blood without subsequent transfer into hair (as hair was in the quiescent phase). Therefore, this study design was not able to address the blood-to-hair correlation. To do so, newly grown hair after moulting should be sampled.

\section{Conclusion}

This first report of the quantification of non-essential metal(loid)s in blood and hair of European brown bear revealed $\mathrm{Pb}$ as the most abundant metal that is possibly toxicologically relevant for bears. In $11 \%$ of individuals, blood $\mathrm{Pb}$ levels surpassed human threshold levels applied due to the lack of wildlife threshold data. The association between $\mathrm{Pb}$ and a biomarker of oxidative stress (activity of enzyme SOD) and some essential elements ( $\mathrm{Mn}, \mathrm{Zn}$ and Mo) indicated the need for larger sample scale studies to explore possible $\mathrm{Pb}$-related adverse health effects in brown bear. Higher non-essential ( $\mathrm{Cd}, \mathrm{Tl}$ and $\mathrm{Pb}$ ) and essential metal levels (Mn, Zn, Co) in free-ranging compared to captive bears confirmed habitat and diet differences. Significant influence of confounding factors (age, sex, status, country, hair growth phase) on metal (loid)s level and even some oxidative stress biomarkers, imply the importance of the inclusion of these elements in future biomonitoring studies of apex terrestrial mammals. Hair sampled throughout the year did not reflect non-essential metal(loid) levels in bear blood. Brown bears from this study had non-essential and essential metal(loid)s in the range of currently available ursid and wildlife data, under the toxic thresholds and within the normal levels for essential elements published for domestic animals and wild mammals.

\section{Funding sources}

Financing for this research included the Ministry of Science and Education of the Republic of Croatia through Institutional Funding, the European Commission under the "HUNT" project of the 7th Framework Programme for Research and Technological Development (grant no. 212160), "LIFE DINALP BEAR" project (grant No. LIFE13 NAT/SI/ 000550), the Research Council of Norway under the project "The role of natural resources in sustainable rural livelihoods in the western Balkans. The distribution and flow of costs and benefits" (application No. ES459363), EuroNatur (grant no. HR-17-500-08), Bernd Thies Foundation and annual grants from Plitvice Lakes National Park. Research contributing to these results was also funded by the PolishNorwegian Research Programme operated by the National Centre for Research and Development in Poland under the Norwegian Financial Mechanism 2009-2014 in the frame of project contract no. POL-NOR/ 198352/85/2013.(GLOBE), and has also received funding from the European Union's Horizon 2020 research and innovation programme under the Marie Skłodowska-Curie grant agreement No 665778 through National Science Centre in Poland, within the frames of project no. 2016/23/P/NZ9/03951 (BearHealth). Funding agencies and bodies had no involvement in study design, the collection, analysis or interpretation of data, report writing, or the decision to submit the article for publication.

Sample collection in Croatia was approved by the Ministry of Agriculture of the Republic of Croatia, Directorate for Forestry, Hunting and Wood Industry (annual permit no. UP/1-323-03/15-01/107) and Ministry of Environment and Energy (permit no. UP/I-612-07/15-48/ 47). Sample collection in Poland was approved by the General
Directorate for Environmental Protection (permit nos. DOPOZ.6401.08.2.2013.1s.1 and DOP-WG.6401.08.4.2014.JRO,kka) and the appropriate Ethics Committee (Local Ethics Committee in Krakow, permit no. 21/2013).

\section{CRediT authorship contribution statement}

Maja Lazarus: Conceptualization, Formal analysis, Writing - original draft, Visualization. Tatjana Orct: Methodology, Formal analysis. Agnieszka Sergiel: Investigation, Resources, Data curation, Writing review \& editing, Project administration, Funding acquisition. Lana Vranković: Formal analysis, Investigation, Resources. Vlatka Filipović Marijić: Methodology, Formal analysis, Investigation, Writing - review \& editing. Dubravka Rašić: Methodology, Formal analysis. Slaven Reljić: Resources, Writing - review \& editing. Jasna Aladrović: Validation, Formal analysis, Resources. Tomasz Zwijacz-Kozica: Investigation, Resources, Writing - review \& editing. Filip Zięba: Investigation, Resources. Jasna Jurasović: Resources, Funding acquisition. Marijana Erk: Supervision, Writing - review \& editing. Robert Maślak: Resources. Nuria Selva: Resources, Writing - review \& editing, Funding acquisition. Đuro Huber: Resources, Writing - review \& editing, Supervision.

\section{Declaration of competing interest}

The authors have no competing interests to declare.

\section{Acknowledgements}

We would like to thank local hunters and experts from Poland and Croatia, the Carpathian Brown Bear Project, and Tatra National Park teams for providing hair samples, and all project members who assisted in the field during captures, handling and sample collection. We also thank the Royal Society for Prevention of Cruelty to Animals (RSPCA), Four Paws, Johanna Painer, Frank Göritz and Michał Bednarski for support and assistance in veterinary procedures during which the samples of Polish captive bears were collected. Maja Szymańska and bear keepers in all captive institutions are thanked for their valuable support during the examinations. The authors wish to thank Makso Herman and Linda Zanella for language editing.

\section{Appendix A. Supplementary data}

Supplementary data to this article can be found online at https:// doi.org/10.1016/j.envres.2020.109166.

\section{References}

Adam, V., Beklova, M., Pikula, J., Hubalek, J., Trnkova, L., Kizek, R., 2007. Shapes of differential pulse voltammograms and level of metallothionein at different animal species. Sensors 7 (10), 2419-2429. https://doi.org/10.3390/s7102419.

Toxic Substances and Disease Registry (ATSDR), 2019. Toxicological profile for Lead. U.S. Department of Health and Human Services, Public Health Service, Atlanta, GA. https://www.atsdr.cdc.gov/ToxProfiles/tp.asp?id = 96\&amp;tid=22, Accessed date: 20 June 2019.

Agency for Toxic Substances and Disease Registry (ATSDR), 2012. Toxicological Profile for Cadmium. U.S. Department of Health and Human Services, Public Health Service, Atlanta, GA. https://www.atsdr.cdc.gov/toxprofiles/TP.asp?id $=48 \&$ tid $=15$, Accessed date: 21 March 2019.

Barbosa, F., Tanus-Santos, J.E., Gerlach, R.F., Parsons, P.J., 2005. A Critical review of biomarkers used for monitoring human exposure to lead: advantages, limitations, and future needs. Environ. Health Perspect. 113 (12), 1669-1674.

Bechshoft, T., Derocher, A.E., Richardson, E., Lunn, N.J., St Louis, V.L., 2016. Hair mercury concentrations in Western Hudson Bay polar bear family groups. Environ. Sci. Technol. 50 (10), 5313-5319.

Berzas Nevado, J.J., Rodríguez Martín-Doimeadios, R.C., Mateo, R., Rodríguez Fariñas, N., Rodríguez-Estival, J., Patiño Ropero, M.J., 2012. Mercury exposure and mechanism of response in large game using the Almadén mercury mining area (Spain) as a case study. Environ. Res. 112, 58-66.

Bojarska, K., 2015. Trophic Ecology of the Brown Bear: from Biogeographical to Individual Point of View. PhD thesis. Jagiellonian University, Faculty of Biology and 
Earth Sciences, Institute of Environmental Sciences, Krakow.

Buekers, J., Redeker, E.S., Smolders, E., 2009. Lead toxicity to wildlife: derivation of a critical blood concentration for wildlife monitoring based on literature data. Sci. Total Environ. 407 (11), 3431-3438.

Burco, J., Myers, A.M., Schuler, K., Gillin, C., 2012. Acute lead toxicosis via ingestion of spent ammunition in a free-ranging cougar (Puma concolor). J. Wildl. Dis. 48 (1), 216-219.

Burger, J., Fossi, C., McClellan-Green, P., Orlando, E.F., 2007. Methodologies, bioindicators, and biomarkers for assessing gender-related differences in wildlife exposed to environmental chemicals. Environ. Res. 104 (1), 135-152.

Cardona-Marek, T., Knott, K.K., Meyer, B.E., O'Hara, T.M., 2009. Mercury concentrations in Southern Beaufort Sea polar bears: variation based on stable isotopes of carbon and nitrogen. Environ. Toxicol. Chem. 28 (7), 1416-1424.

Cattet, M., Stenhouse, G.B., Boulanger, J., Janz, D.M., Kapronczai, L., Swenson, J.E., Zedrosser, A., 2018. Can concentrations of steroid hormones in brown bear hair reveal age class? Conserv. Physiol. 6 (1), 1-20.

Chapron, G., et al., 2014. Recovery of large carnivores in Europe's modern humandominated landscapes. Science 346, 1517-1519.

Chen, Y.P., Liu, Q., Ma, Q.Y., Maltby, L., Ellison, A.M., Zhao, Y., 2018. Environmental toxicants impair liver and kidney function and sperm quality of captive pandas. Ecotoxicol. Environ. Saf. 162, 218-224.

Cicnjak, L., Huber, Đ., Roth, H.U., Ruff, R.L., Vinovrški, Z., 1987. Food habits of brown bears in Plitvice Lakes national Park, Yugoslavia. In: International Conf. Bear Res. Manage., vol. 7. pp. 221-226.

Čelechovská, O., Literák, I., Ondruš, S., Pospíšil, Z., 2006. Heavy metals in brown bears from the central European Carpathians. Acta Vet. 75, 501-506.

Dainowski, B.H., Duffy, L.K., McIntyre, J., Jones, P., 2015. Hair and bone as predictors of tissular mercury concentration in the western Alaska red fox, Vulpes vulpes. Sci. Total Environ. 518-519, 526-533.

Dietz, R., Sonne, C., Basu, N., Braune, B., O'Hara, T., Letcher, R.J., Scheuhammer, T., Andersen, M., Andreasen, C., Andriashek, D., Asmund, G., Aubail, A., Baagøe, H., Born, E.W., Chan, H.M., Derocher, A.E., Grandjean, P., Knott, K., Kirkegaard, M., Krey, A., Lunn, N., Messier, F., Obbard, M., Olsen, M.T., Ostertag, S., Peacock, E., Renzoni, A., Rigét, F.F., Skaare, J.U., Stern, G., Stirling, I., Taylor, M., Wiig, Ø., Wilson, S., Aars, J., 2013. What are the toxicological effects of mercury in Arctic biota? Sci. Total Environ. 443, 775-790.

Drury, J.A., Nycyk, J.A., Cooke, R.W.I., 1997. Comparison of urinary and plasma malondialdehyde in preterm infants. Clin. Chim. Acta 263, 177-185.

Durkalec, M., Kolenda, R., Owczarek, T., Szkoda, J., Nawrocka, A., Grzegrzółka, J., Dziegiel, P., Socha, P., Kołacz, R., Schierack, P., Żmudzki, J., Posyniak, A., 2017. Expression of metallothionein in the liver and kidneys of the red deer (Cervus elaphus L.) from an industrial metal smelting area of Poland. Ecotoxicol. Environ. Saf. 137, 121-129.

Durkalec, M., Nawrocka, A., Krzysiak, M., Larska, M., Kmiecik, M., Posyniak, A., 2018. Trace elements in the liver of captive and free-ranging European bison (Bison bonasus L.). Chemosphere 193, 454-463.

EC/European Council Directive 92/43/EEC of 21 May 1992 on the conservation of natural habitats and of wild fauna and flora. ELI. http://data.europa.eu/eli/dir/1992/ 43/2007-01-01, Accessed date: 15 February 2019.

Ercal, N., Gurer-Orhan, H., Aykin-Burns, N., 2001. Toxic metals and oxidative stress part I: mechanisms involved in metal-induced oxidative damage. Curr. Top. Med. Chem. 1 (6), 529-539.

Ettinger, A.S., Leonard, M.L., Mason, J., 2019. CDC's Lead Poisoning Prevention Program: a long-standing responsibility and commitment to protect children from lead exposure. J. Publ. Health Manag. Pract. 25 (Suppl. 1), S5-S12.

Felicetti, L.A., Schwartz, C.C., Rye, R.O., Gunther, K.A., Crock, J.G., Haroldson, M.A., Waits, L., Robbins, C.T., 2004. Use of naturally occurring mercury to determine the importance of cutthroat trout to Yellowstone grizzly bears. Can. J. Zool. 82 (3), 493-501.

Flaten, T.P., Andersen, L.H., Holsen, A.M.H., Ottemo, V.G., Pedersen, H.C., Steinnes, E., Lierhagen, S., Jenssen, B.M., 2008. A nationwide survey of trace elements in lynx, wolverines, wolves, and brown bears in Norway. Cell Biol. Toxicol. 24 (Suppl. 1), 6-7.

Flora, G., Gupta, D., Tiwari, A., 2012. Toxicity of lead: a review with recent updates. Interdiscipl. Toxicol. 5 (2), 47-58.

Gamberg, M., Scheuhammer, A.M., 1994. Cadmium in caribou and muskoxen from the Canadian Yukon and northwest territories. Sci. Total Environ. 143 (2-3), 221-234.

Goyer, R.A., 1997. Toxic and essential metal interactions. Annu. Rev. Nutr. 17, 37-50.

Herceg Romanić, S., Klinčić, D., Kljaković-Gašpić, Z., Kusak, J., Reljić, S., Huber, Đ., 2015. Organochlorine pesticides and polychlorinated biphenyl congeners in wild terrestrial mammals from Croatia: interspecies comparison of residue levels and compositions. Chemosphere 137, 52-58.

Hernández-Moreno, D., de la Casa Resino, I., Fidalgo, L.E., Llaneza, L., Soler Rodríguez, F., Pérez-López, M., López-Beceiro, A., 2013. Noninvasive heavy metal pollution assessment by means of Iberian wolf (Canis lupus signatus) hair from Galicia (NW Spain): a comparison with invasive samples. Environ. Monit. Assess. 185 (12), 10421-10430.

Hinkle, D.E., Wiersma, W., Jurs, S.G., 2003. Applied Statistics for the Behavioural Sciences, fifth ed. Houghton Mifflin, Boston.

Huber, Đ., Kusak, J., Radišić, B., 1996. Analysis of efficiency in live-capturing of European brown bears. J. Wildl. Res. 1 (2), 158-162.

Huber, Đ., Kusak, J., Majić Skrbinšek, A., Majnarić, D., Sindičić, M., 2008. A multidimensional approach to managing the European brown bear in Croatia. Ursus 19, 22-32.

Isani, G., Carpenè, E., 2014. Metallothioneins, unconventional proteins from unconventional animals: a long journey from nematodes to mammals. Biomolecules 4 (2),
435-457.

Ivanković, D., Pavičić, J., Erk, M., Filipović Marijić, V., Raspor, B., 2005. Evaluation of the Mytilus galloprovincialis Lam. digestive gland metallothionein as a biomarker in a long-term field study: seasonal and spatial variability. Mar. Pollut. Bull. 50 (11), 1303-1313. https://doi.org/10.1016/j.marpolbul.2005.04.039.

Julian, P., Cunningham, M.W., 2013. Total mercury concentrations in Florida black bears (Ursus americanus floridanus). Fla. Sci. 76, 1-6.

Kaczensky, P., Knauer, F., Jonozović, M., Walzer, C., Huber, T., 2002. Experiences with trapping, chemical immobilization, and radiotagging of brown bears in Slovenia. Ursus 13, 347-356.

Kaczensky, P., Chapron, G., Arx, M., Huber, Đ., Andrén, H., Linnell, J., 2012. Status, Management and Distribution of Large Carnivores - Bear, lynx, Wolf \& Wolverine - in Europe. Istituto di Ecologia Applicata and the IUCN/SSC Large Carnivore Initiative for Europe report prepared for the European Commission (contract $N^{\circ} 070307 / 2012$ / 629085/SER/B3). https://ec.europa.eu/environment/nature/conservation/species/ carnivores/pdf/task_1_part2_species_country_reports.pdf, Accessed date: 23 September 2018.

Kägi, J.H., 1991. Overview of metallothionein. Methods Enzymol. 205, 613-626.

Kalisińska, E., 2019. Endothermic animals as biomonitors of terrestrial environments. In: Kalisińska, E. (Ed.), Mammals and Birds as Bioindicators of Trace Element Contaminations in Terrestrial Environments. Springer Nature Switzerland AG, pp. 21-53.

Klaassen, C.D., Liu, J., Choudhuri, S., 1999. Metallothionein: an intracellular protein to protect against cadmium toxicity. Annu. Rev. Pharmacol. Toxicol. 39, 267-294.

Klaassen, C.D., Casarett, L.J., Doull, J., 2013. In: Klaassen, C.D. (Ed.), Casarett \& Doull's Toxicology: the Basic Science of Poisons. McGrow-Hill Education, New York.

Kusak, J., Huber, Đ., 1998. Brown bear habitat quality in Gorski Kotar, Croatia. Ursus 10, 281-291.

Lazarus, M., Orct, T., Reljić, S., Sedak, M., Bilandžić, N., Jurasović, J., Huber, Đ., 2018a. Trace and macro elements in the femoral bone as indicators of long-term environmental exposure to toxic metals in European brown bear (Ursus arctos) from Croatia Environ. Sci. Pollut. Res. 25 (22), 21656-21670.

Lazarus, M., Sekovanić, A., Orct, T., Reljić, S., Jurasović, J., Huber, Đ., 2018b. Sexual maturity and life stage influences toxic metal accumulation in Croatian brown bears. Arch. Environ. Contam. Toxicol. 74 (2), 339-348.

Lazarus, M., Sekovanić, A., Orct, T., Reljić, S., Kusak, J., Jurasović, J., Huber, Đ., 2017. Apex predatory mammals as bioindicator species in environmental monitoring of elements in Dinaric Alps (Croatia). Environ. Sci. Pollut. Res. 24 (30), 23977-23991.

Lazarus, M., Orct, T., Blanuša, M., Vicković, I., Šoštarić, B., 2008. Toxic and essential metal concentrations in four tissues of red deer (Cervus elaphus) from Baranja, Croatia. Food Addit. Contam. Part A Chem. Anal. Control Expo. Risk Assess. 25 (3), 270-283.

Lieske, C.L., Moses, S.K., Castellini, J.M., Klejka, J., Hueffer, K., O'Hara, T.M., 2011 Toxicokinetics of mercury in blood compartments and hair of fish-fed sled dogs. Acta Vet. Scand. 53, 66. https://doi.org/10.1186/1751-0147-53-66.

Ma, W.C., 2011. Lead in mammals. In: Beyer, W.N., Meador, J.P. (Eds.), Environmental Contaminants in Biota: Interpreting Tissue Concentrations, second ed. CRC Press Inc Boca Raton, USA, pp. 595-608.

Malvandi, H., Ghasempouri, S.M., Esmaili-Sari, A., Bahramifar, N., 2010. Evaluation of the suitability of application of golden jackal (Canis aureus) hair as a noninvasive technique for determination of body burden mercury. Ecotoxicology 19 (6), 997-1002.

Martin, A., Müller-Graf, C., Selhorst, T., Gerofke, A., Ulbig, E., Gremse, C., Greiner, M., Lahrssen-Wiederholt, M., Hensel, A., 2019. Comparison of lead levels in edible parts of red deer hunted with lead or non-lead ammunition. Sci. Total Environ. 653, 315-326.

Matović, V., Buha, A., Đukić-Ćosić, D., Bulat, Z., 2015. Insight into the oxidative stress induced by lead and/or cadmium in blood, liver and kidneys. Food Chem. Toxicol. 78, 130-140.

Matson, G., Van Daele, L., Goodwin, E., Aumiller, L., Reynolds, H., Hristienko, H., 1993. A laboratory manual for cementum age determination of Alaska brown bear first premolar teeth. Alaska Department of Fish and Game, Division of Wildlife Conservation, Anchorage, Alaska.

Medvedev, N., 1999. Levels of heavy metals in Karelian wildlife, 1989-91. Environ. Monit. Assess. 56, 177-193.

M'kandawire, E., Syakalima, M., Muzandu, K., Pandey, G., Simuunza, M., Nakayama, S.M., Kawai, Y.K., Ikenaka, Y., Ishizuka, M., 2012. The nucleotide sequence of metallothioneins (MT) in liver of the Kafue lechwe (Kobus leche kafuensis) and their potential as biomarkers of heavy metal pollution of the Kafue River. Gene 506 (2), 310-316.

Murphy, S.M., Ulrey, W.A., Guthrie, J.M., Maehr, D.S., Abrahamson, W.G., Maehr, S.C., Cox, J.J., 2017. Food habits of a small Florida black bear population in an endangered ecosystem. Ursus 28 (1), 92-104.

Noël, M., Spence, J., Harris, K.A., Robbins, C.T., Fortin, J.K., Ross, P.S., Christensen, J.R., 2014. Grizzly bear hair reveals toxic exposure to mercury through salmon consumption. Environ. Sci. Technol. 48 (13), 7560-7567.

Noël, M., Christensen, J.R., Spence, J., Robbins, C.T., 2015. Using laser ablation inductively coupled plasma mass spectrometry (LA-ICP-MS) to characterize copper, zinc and mercury along grizzly bear hair providing estimate of diet. Sci. Total Environ. 529, 1-9.

Peraza, M.A., Ayala-Fierro, F., Barber, D.S., Casarez, E., Rael, L.T., 1998. Effects of micronutrients on metal toxicity. Environ. Health Perspect. 106 (Suppl. 1), 203-216.

Peter, A.L., Viraraghavan, T., 2005. Thallium: a review of public health and environmental concerns. Environ. Int. 31, 493-501.

Peterson, S.H., Ackerman, J.T., Costa, D.P., 2016. Mercury correlations among blood, muscle, and hair of northern elephant seals during the breeding and molting fasts. 
Environ. Toxicol. Chem. 35 (8), 2103-2110.

Polizzi, P., Romero, M.B., Chiodi Boudet, L.N., Ponce de León, A., Medici, S., Costas, A., Rodríguez, D., Gerpe, M., 2017. Blood cadmium and metallothionein concentrations in females of two sympatric pinnipeds species. Mar. Pollut. Bull. 122 (1-2), 446-449.

Puls, R., 1994. Mineral levels in animal health. Diagnostic data. Sherpa International, Clearbrook.

Raspor, B., Paić, M., Erk, M., 2001. Analysis of metallothioneins by the modified Brdička procedure. Talanta 55, 109-115.

Reglero, M.M., Taggart, M.A., Monsalve-González, L., Mateo, R., 2009. Heavy metal exposure in large game from a lead mining area: effects on oxidative stress and fatty acid composition in liver. Environ. Pollut. 157, 1388-1395.

Rodríguez-Estival, J., Mateo, R., 2019. Exposure to anthropogenic chemicals in wild carnivores: a silent conservation threat demanding long-term surveillance. Curr. Opin. Environ. Sci. Health 11, 21-25.

Rodríguez-Estival, J., de la Lastra, J.M., Ortiz-Santaliestra, M.E., Vidal, D., Mateo, R., 2013. Expression of immunoregulatory genes and its relationship to lead exposure and lead-mediated oxidative stress in wild ungulates from an abandoned mining area. Environ. Toxicol. Chem. 32 (4), 876-883.

Rodríguez-Estival, J., Barasona, J.A., Mateo, R., 2012. Blood Pb and $\delta$-ALAD inhibition in cattle and sheep from a Pb-polluted mining area. Environ. Pollut. 160 (1), 118-124.

Rodríguez-Estival, J., Martinez-Haro, M., Monsalve-González, L., Mateo, R., 2011. Interactions between endogenous and dietary antioxidants against Pb-induced oxidative stress in wild ungulates from a Pb polluted mining area. Sci. Total Environ. 409, 2725-2733.

Rodríguez-Jorquera, I.A., Vitale, N., Garner, L., Perez-Venegas, D.J., Galbán-Malagón, C.J., Duque-Wilckens, N., Toor, G.S., 2017. Contamination of the upper class: occurrence and effects of chemical pollutants in terrestrial top predators. Curr. Pollut. Rep. 3, 206-219.

Rogers, T.A., Bedrosian, B., Graham, J., Foresman, K.R., 2012. Lead exposure in large carnivores in the greater Yellowstone ecosystem. J. Wildl. Manag. 76, 575-582.

Ryabukhin, Yu S., 1976. In: Ryabukhin, Yu S. (Ed.), Activation Analysis of Hair as an Indicator of Contamination of Man by Environmental Trace Element Pollutants. IAEA, Seibersdorf, Austria.

Scheuhammer, A., Braune, B., Chan, H.M., Frouin, H., Krey, A., Letcher, R., Loseto, L., Noël, M., Ostertag, S., Ross, P., Wayland, M., 2015. Recent progress on our understanding of the biological effects of mercury in fish and wildlife in the Canadian Arctic. Sci. Total Environ. 509-510, 91-103.

Selva, N., Zwijacz-Kozica, T., Sergiel, A., Olszańska, A., Zięba, F., 2011. The Brown Bear
Management Plan for Poland. Warsaw University of Life Sciences, Warsaw, Poland. Stohs, S.J., Bagchi, D., 1995. Oxidative mechanisms in the toxicity of metal ions. Free Radic. Biol. Med. 18 (2), 321-336.

Swenson, J.E., Gerstl, N., Dahle, B., Zedrosser, A., 2000. Action plan for the conservation of the brown bear in Europe (Ursus arctos). Nat. Environ. 114, 1-70 Strasbourg Cedex, Council of Europe.

Šprem, N., Piria, M., Barišić, D., Kusak, J., Barišić, D., 2016. Dietary items as possible sources of ${ }^{137} \mathrm{Cs}$ in large carnivores in the Gorski kotar forest ecosystem, Western Croatia. Sci. Total Environ. 826-832 542A.

Taggart, M.A., Reglero, M.M., Camarero, P.R., Mateo, R., 2011. Should legislation regarding maximum $\mathrm{Pb}$ and $\mathrm{Cd}$ levels in human food also cover large game meat? Environ. Int. 31, 18-25.

Tchounwou, P.B., Yedjou, C.G., Patlolla, A.K., Sutton, D.J., 2012. Heavy metals toxicity and the environment. Exper. Suppl. (Basel) 101, 133-164.

Telišman, S., 1995. Interactions of essential and/or toxic metals and metalloid regarding interindividual differences in susceptibility to various toxicants and chronic diseases in man. Arh. Hig. Rada. Toksikol. 46 (4), 459-476.

Travis, E.K., Watson, P., Dabek, L., 2012. Health assessment of free-ranging and captive Matschie's tree kangaroos (Dendrolagus matschiei) in Papua New Guinea. J. Zoo Wildl Med. 43 (1), 1-9.

Treu, G., Krone, O., Unnsteinsdóttir, E.R., Greenwood, A.D., Czirják, G.Á., 2018. Correlations between hair and tissue mercury concentrations in Icelandic arctic foxes (Vulpes lagopus). Sci. Total Environ. 619-620, 1589-1598.

Uba, I., 2013. Concentrations of selected chemical elements in organs and tissues of polar bears (Ursus maritimus) from East Greenland. Master's thesis. Norwegian Univ. Sci. Technol Trondheim. https://ntnuopen.ntnu.no/ntnu-xmlui/bitstream/handle/ 11250/245342/660434 FULLTEXT01.pdf?sequence $=1$ \&isAllowed $=\mathrm{y}$, Accessed date: 20 January 2019.

Vihnanek Lazarus, M., Sekovanić, A., Kljaković-Gašpić, Z., Orct, T., Jurasović, J., Kusak, J., Reljić, S., Huber, Đ., 2013. Cadmium and lead in grey wolf liver samples: optimization of a microwave-assisted digestion method. Arh. Hig. Rada. Toksikol. 64, 395-403.

Ważna, A., Cichocki, J., Mierczak, Z., Zwijacz-Kozica, T., 2017. The Diet of Brown Bear Ursus arctos in the Tatra National Park. $25^{\text {th }}$ International Conference on Bear Research and Management, Quito 2017. Book of Abstracts, pp. 205.

Živković, T., Tariba, B., Pizent, A., 2014. Multielement analysis of human seminal plasma by octopole reaction cell ICP-MS. J. Anal. At. Spectrom. 29 (11), 2114-2126. 


\section{Supplementary material}

Journal: Environmental Research

Title: Metal(loid) exposure assessment and biomarker responses in captive and free-ranging European brown bear (Ursus arctos)

Authors: Maja Lazarus, Tatjana Orct, Agnieszka Sergiel, Lana Vranković, Vlatka Filipović Marijić, Dubravka Rašić, Slaven Reljić, Jasna Aladrović, Tomasz ZwijaczKozica, Filip Zięba, Jasna Jurasović, Marijana Erk, Robert Maślak, Nuria Selva, Đuro Huber

Corresponding author:

Maja Lazarus

Institute for Medical Research and Occupational Health

Ksaverska cesta 2, P.O. Box 291, HR-10001 Zagreb, Croatia

Tel: 0038514682539

Fax: 0038514673303

E-mail:mlazarus@imi.hr

Supplementary material contains: 7 Tables 
Table A.1 Method detection limit (MDL) ${ }^{1}$ for metal(loid) quantification in brown bear hair and results of the analyses of standard/certified reference materials used for quality control

\begin{tabular}{|c|c|c|c|c|c|c|c|c|}
\hline \multirow{2}{*}{\multicolumn{2}{|c|}{ Element }} & \multirow{2}{*}{$\begin{array}{l}\mathrm{MDL}^{\mathrm{a}} \\
\text { hair }\end{array}$} & \multirow{2}{*}{\multicolumn{2}{|c|}{ IAEA-086 Human hair }} & \multirow{2}{*}{\multicolumn{2}{|c|}{ NIES CRM No.13 Human hair }} & \multirow{2}{*}{\multicolumn{2}{|c|}{ NIST SRM 1577a Bovine liver }} \\
\hline & & & & & & & & \\
\hline $\mathrm{Mg}$ & $\mathrm{mg} / \mathrm{kg}$ & 551 & $177(156-197)^{2}$ & $174+6$ & $160^{2}$ & $157(155-160)$ & $600(585-615)$ & $591+12$ \\
\hline $\mathrm{Ca}$ & $\mathrm{mg} / \mathrm{kg}$ & 18.5 & $1120(1000-1240)^{2}$ & $1114 \pm 26$ & $820^{2}$ & $819(809-830)$ & $120(113-127)$ & $118 \pm 6$ \\
\hline $\mathrm{Mn}$ & $\mathrm{mg} / \mathrm{kg}$ & 0.037 & $9.6(8.9-10.3)^{2}$ & $9.9 \pm 0.4$ & $3.9^{2}$ & $4.0(3.9-4.1)$ & $9.9(9.1-10.7)$ & $9.9 \pm 0.2$ \\
\hline $\mathrm{Fe}$ & $\mathrm{mg} / \mathrm{kg}$ & 2.81 & $123(110-136)$ & $123 \pm 3$ & $140^{2}$ & $137(136-138)$ & $194(174-214)$ & $182 \pm 4$ \\
\hline Co & $\mu g / k g$ & 8.14 & - & - & $70^{2}$ & $71(68-73)$ & $210(160-260)$ & $221 \pm 6$ \\
\hline $\mathrm{Cu}$ & $\mathrm{mg} / \mathrm{kg}$ & 0.152 & $17.6(16.6-18.5)^{2}$ & $18.1 \pm 0.6$ & $15.3(14.0-16.6)$ & $14.9(14.5-15.3)$ & $158(151-165)$ & $155 \pm 6$ \\
\hline $\mathrm{Zn}$ & $\mathrm{mg} / \mathrm{kg}$ & 1.12 & $167(159-174)$ & $166 \pm 6$ & $172(161-183)$ & $173(166-179)$ & $123(115-131)$ & $129 \pm 6$ \\
\hline As & $\mu g / k g$ & 22.4 & - & - & $100^{2}$ & $101(96-106)$ & $47(41-53)$ & $51 \pm 2$ \\
\hline $\mathrm{Se}$ & $\mu \mathrm{g} / \mathrm{kg}$ & 35.6 & $1000(800-1200)^{2}$ & $980 \pm 49$ & $1790(1620-1960)$ & $1755(1717-1793)$ & $710(640-780)$ & $701 \pm 39$ \\
\hline Mo & $\mu \mathrm{g} / \mathrm{kg}$ & 12.0 & - & - & - & - & $3500(3000-4000)$ & $3485 \pm 75$ \\
\hline $\mathrm{Cd}$ & $\mu \mathrm{g} / \mathrm{kg}$ & 6.37 & - & - & $230(200-260)$ & 219 (211-227) & $440(380-500)$ & $415 \pm 22$ \\
\hline $\mathrm{Hg}$ & $\mu \mathrm{g} / \mathrm{kg}$ & 43.0 & 573 (534-612) & 577 (547-607) & $4420(4220-4620)$ & $4436(4404-4468)$ & - & - \\
\hline TI & $\mu \mathrm{g} / \mathrm{kg}$ & 0.600 & - & - & - & - & - & - \\
\hline $\mathrm{Pb}$ & $\mu \mathrm{g} / \mathrm{kg}$ & 16.8 & - & - & $4600(4200-5000)$ & 4597 (4494-4700) & $135(120-150)$ & $125 \pm 12$ \\
\hline
\end{tabular}

${ }^{1}$ Method detection limit (MDL) is calculated as the mean plus three times the standard deviation of a set of method blanks multiplied by the dilution factor

2Non-certified (information) values 
Table A.2 Method detection limit (MDL) ${ }^{1}$ for metal(loid) quantification in brown bear blood compartments and results of the analyses of standard/certified reference materials used for quality control

\begin{tabular}{|c|c|c|c|c|c|c|c|c|}
\hline \multicolumn{2}{|c|}{ Element } & \multirow{2}{*}{$\begin{array}{l}\text { MDL }^{\mathrm{a}} \\
\text { whole } \\
\text { blood }\end{array}$} & \multicolumn{2}{|c|}{ Seronorm Whole blood L-1 } & \multicolumn{2}{|c|}{ Seronorm Whole blood L-2 } & \multicolumn{2}{|c|}{ Seronorm Whole blood L-3 } \\
\hline & & & $\begin{array}{l}\text { Certified } \\
(\text { mean }(95 \% \mathrm{Cl}))\end{array}$ & $\begin{array}{l}\text { Measured } \\
\text { (mean } \pm S D)\end{array}$ & $\begin{array}{l}\text { Certified } \\
(\text { mean }(95 \% \mathrm{Cl}))\end{array}$ & $\begin{array}{l}\text { Measured } \\
(\text { mean } \pm S D)\end{array}$ & $\begin{array}{l}\text { Certified } \\
(\text { mean }(95 \% \text { CI }))\end{array}$ & $\begin{array}{l}\text { Measured } \\
(\text { mean } \pm S D)\end{array}$ \\
\hline $\mathrm{Mg}$ & $\mathrm{mg} / \mathrm{L}$ & 0.0027 & $14.7^{2}$ & $14.2(13.8-14.6)$ & $14.4^{2}$ & $14.0(13.8-14.1)$ & $17.2^{2}$ & $15.5(15.2-15.9)$ \\
\hline $\mathrm{Ca}$ & $\mathrm{mg} / \mathrm{L}$ & 0.208 & $15.0^{2}$ & $14.9(14.7-15.2)$ & $15.0^{2}$ & $14.4(14.2-14.6)$ & $14.2^{2}$ & $13.2(12.2-14.3)$ \\
\hline $\mathrm{Mn}$ & $\mu \mathrm{g} / \mathrm{L}$ & 0.750 & $18.4(14.7-22.1)$ & $18.5(18.4-18.6)$ & $31.4(25.1-37.7)$ & $31.8(31.4-31.7)$ & $47.3(37.8-56.8)$ & $47.5(47.1-47.9)$ \\
\hline $\mathrm{Fe}$ & $\mathrm{mg} / \mathrm{L}$ & 0.730 & $334^{2}$ & $333(320-347)$ & $332^{2}$ & $330(317-344)$ & $383^{2}$ & $386(373-399)$ \\
\hline Co & $\mu \mathrm{g} / \mathrm{L}$ & 0.149 & $0.20(0.12-0.28)$ & $0.22(0.20-0.24)$ & $5.18(4.13-6.22)$ & $5.12(5.06-5.19)$ & $11.4(10.2-12.6)$ & $11.5(11.3-11.7)$ \\
\hline $\mathrm{Cu}$ & $\mathrm{mg} / \mathrm{L}$ & 0.022 & $0.64(0.51-0.76)$ & $0.65(0.64-0.65)$ & $1.34(1.07-1.60)$ & $1.32(1.31-1.34)$ & $2.47(2.22-2.72)$ & $2.44(2.36-2.53)$ \\
\hline $\mathrm{Zn}$ & $\mathrm{mg} / \mathrm{L}$ & 0.025 & $4.3(3.4-5.2)$ & $4.41(4.39-4.43)$ & $7.1(5.7-8.5)$ & $7.4(7.3-7.4)$ & $9.11(7.28-10.9)$ & $9.01(8.97-9.06)$ \\
\hline As & $\mu \mathrm{g} / \mathrm{L}$ & 2.37 & $4.6(3.7-5.5)$ & $2.1(1.9-2.3)$ & $14.1(11.3-17.0)$ & $13.8(13.2-14.5)$ & $30.4(23.1-37.7)$ & $29.7(28.8-30.6)$ \\
\hline Mo & $\mu \mathrm{g} / \mathrm{L}$ & 0.456 & $0.51(0.41-0.61)$ & $0.67(0.65-0.70)$ & $5.31(4.24-6.37)$ & $5.3(5.1-5.5)$ & $7.5(6.0-9.0)$ & $7.5(7.3-7.7)$ \\
\hline $\mathrm{Cd}$ & $\mu \mathrm{g} / \mathrm{L}$ & 0.247 & $0.28(0.17-0.40)$ & $0.270(0.26-0.28)$ & $5.01(4.00-6.20)$ & $5.2(5.1-5.3)$ & $12.1(10.8-13.4)$ & $11.9(11.7-12.2)$ \\
\hline $\mathrm{Hg}$ & $\mu \mathrm{g} / \mathrm{L}$ & 1.31 & $1.48(1.18-1.77)$ & $1.48(1.48-1.49)$ & $17.0(13.6-20.4)$ & $18.5(18.4-18.6)$ & $37.1(29.6-44.6)$ & $37.7(37.5-37.9)$ \\
\hline TI & $\mu \mathrm{g} / \mathrm{L}$ & 0.031 & $0.007(0.003-0.011)$ & $<M D L$ & $10.2(8.1-12.2)$ & $10.8(10.1-11.5)$ & $34.1(27.2-41.0)$ & $34.9(34.3-35.5)$ \\
\hline $\mathrm{Pb}$ & $\mu g / L$ & 0.240 & $9.9(7.9-11.9)$ & $10.9(10.8-10.9)$ & $337(269-405)$ & $340(336-344)$ & $447(401-493)$ & $443(440-445)$ \\
\hline \multirow{2}{*}{\multicolumn{2}{|c|}{ Element }} & MDL & \multicolumn{2}{|c|}{ Seronorm Serum L-1 } & \multicolumn{2}{|c|}{ Seronorm Serum L-2 } & & \\
\hline & & serum & $\begin{array}{l}\text { Certified } \\
(\text { mean }(95 \% \text { Cl)) }\end{array}$ & $\begin{array}{l}\text { Measured } \\
(\text { mean } \pm S D)\end{array}$ & $\begin{array}{l}\text { Certified } \\
(\text { mean }(95 \% \mathrm{CI}))\end{array}$ & $\begin{array}{l}\text { Measured } \\
(\text { mean } \pm S D)\end{array}$ & & \\
\hline $\mathrm{Mg}$ & $\mathrm{mg} / \mathrm{L}$ & 0.0008 & $16.8(13.4-20.1)$ & $16.5(16.2-16.8)$ & $33.9(27.1-40.7)^{2}$ & $32.6(32.3-32.8)$ & & \\
\hline $\mathrm{Fe}$ & $\mathrm{mg} / \mathrm{L}$ & 0.208 & $1.47(1.17-1.77)$ & $1.43(1.4-1.5)$ & $2.15(1.72-2.58)^{2}$ & $2.0(2.0-2.1)$ & & \\
\hline Co & $\mu \mathrm{g} / \mathrm{L}$ & 0.043 & $1.12(0.67-1.57)$ & $1.10(1.08-1.11)$ & $3.05(2.13-3.97)^{2}$ & $2.9(2.8-3.0)$ & & \\
\hline $\mathrm{Cu}$ & $\mathrm{mg} / \mathrm{L}$ & 0.0063 & $1.09(0.999-1.18)$ & $1.06(1.03-1.09)$ & $1.85(1.7-2.0)^{2}$ & $1.86(1.85-1.87)$ & & \\
\hline $\mathrm{Zn}$ & $\mathrm{mg} / \mathrm{L}$ & 0.0072 & $1.1(0.952-1.24)$ & $1.1(1.09-1.13)$ & $1.62(0.952-1.24)$ & $1.61(1.57-1.64)$ & & \\
\hline As & $\mu \mathrm{g} / \mathrm{L}$ & 0.678 & $0.40^{2}$ & $0.43(0.41-0.44)$ & $0.38^{2}$ & $0.53(0.50-0.57)$ & & \\
\hline $\mathrm{Se}$ & $\mu \mathrm{g} / \mathrm{L}$ & 0.347 & $87(76-99)$ & $89(87-90)$ & $138(120-157)$ & $138(136-140)$ & & \\
\hline Mo & $\mu \mathrm{g} / \mathrm{L}$ & 0.130 & $0.76^{2}$ & $0.74(0.72-0.75)$ & $1.21^{2}$ & $1.13(1.12-1.14)$ & & \\
\hline $\mathrm{Cd}$ & $\mu \mathrm{g} / \mathrm{L}$ & 0.070 & $0.13^{2}$ & $0.14(0.13-0.14)$ & $0.14^{2}$ & $0.15(0.14-0.15)$ & & \\
\hline $\mathrm{Hg}$ & $\mu \mathrm{g} / \mathrm{L}$ & 0.375 & $1.07(0.53-1.60)$ & $1.07(0.99-1.14)$ & $2.07(1.44-2.67)$ & $1.95(1.93-1.98)$ & & \\
\hline $\mathrm{TI}$ & $\mu \mathrm{g} / \mathrm{L}$ & 0.0089 & $0.090^{2}$ & $0.096(0.089-0.103)$ & $0.108^{2}$ & $0.109(0.102-0.116)$ & & \\
\hline $\mathrm{Pb}$ & $\mu \mathrm{q} / \mathrm{L}$ & 0.068 & $0.40^{2}$ & $0.45(0.44-0.46)$ & $0.66^{2}$ & $0.63(0.63-0.64)$ & & \\
\hline
\end{tabular}

${ }^{1}$ Method detection limit (MDL) is calculated as the mean plus three times the standard deviation of a set of method blanks multiplied by the dilution facto ${ }^{2}$ Non-certified (information) values 
Table A.3 Results of univariate testing influence of single confounding factor on biomarker and metal(loid) levels in blood and hair of European brown bear (Ursus arctos)

\begin{tabular}{|c|c|c|c|c|c|c|c|}
\hline Variable & Compartment & Transformation & Age & $\begin{array}{l}\text { Sex } \\
\text { male/female }\end{array}$ & $\begin{array}{l}\text { Status } \\
\text { captive/free-ranging }\end{array}$ & $\begin{array}{l}\text { Country } \\
\text { Croatia/Poland }\end{array}$ & $\begin{array}{l}\text { Hair growth phase } \\
\text { growth/quiescent }\end{array}$ \\
\hline MT & serum & none & - & - & - & - & na \\
\hline MDA & serum & $\log _{10}(x)$ & - & - & - & - & na \\
\hline SOD & $\begin{array}{l}\text { serum } \\
\text { whole blood }\end{array}$ & $\begin{array}{l}\text { none } \\
\log _{10}(x)\end{array}$ & $r_{S}=-0.54, p<0.001$ & $t(35)=-2.21, p=0.03$ & $\bar{t}(33)=-2.46, p=0.02$ & $t(35)=2.35, p=0.02$ & $\begin{array}{l}\text { na } \\
\text { na }\end{array}$ \\
\hline $\mathrm{Mg}$ & $\begin{array}{l}\text { serum } \\
\text { plasma } \\
\text { whole blood } \\
\text { hair }\end{array}$ & $\begin{array}{l}\text { none } \\
\text { none } \\
\text { none } \\
\sqrt{x}\end{array}$ & $\begin{array}{l}- \\
- \\
- \\
-\end{array}$ & $\begin{array}{l}- \\
- \\
- \\
-\end{array}$ & $\begin{array}{l}t(35)=2.17, p=0.04 \\
- \\
t(48)=2.41, p=0.02\end{array}$ & $\begin{array}{l}- \\
\text { na } \\
- \\
-\end{array}$ & $\begin{array}{c}\text { na } \\
\text { na } \\
\text { na } \\
-\end{array}$ \\
\hline $\mathrm{Ca}$ & $\begin{array}{l}\text { serum } \\
\text { plasma } \\
\text { whole blood } \\
\text { hair } \\
\end{array}$ & $\begin{array}{l}\text { none } \\
\text { none } \\
\text { none } \\
\log _{10}(x)\end{array}$ & $\begin{array}{l}- \\
- \\
- \\
r_{s}=0.33, p=0.03\end{array}$ & $\begin{array}{l}- \\
- \\
- \\
- \\
\end{array}$ & $\begin{array}{l}- \\
- \\
- \\
t(48)=6.68, p<0.001\end{array}$ & $\begin{array}{l}- \\
\text { na } \\
- \\
-\end{array}$ & $\begin{array}{c}\mathrm{na} \\
\text { na } \\
\text { na } \\
-\end{array}$ \\
\hline Mn & $\begin{array}{l}\text { serum } \\
\text { plasma } \\
\text { whole blood } \\
\text { hair } \\
\end{array}$ & $\begin{array}{l}\log _{10}(x) \\
\text { none } \\
\text { none } \\
\log _{10}(x)\end{array}$ & $\begin{array}{l}- \\
- \\
- \\
r_{S}=-0.53, p<0.001\end{array}$ & $\begin{array}{l}t(35)=-2.09, p=0.04 \\
t(16)=-3.17, p=0.006 \\
U=78, p=0.04 \\
-\end{array}$ & $\begin{array}{l}t(35)=-3.08, p=0.004 \\
t(33)=-2.13, p=0.04 \\
t(48)=-4.98, p<0.001\end{array}$ & $\begin{array}{l}-\overline{n a} \\
\mathrm{U}=85, p=0.03 \\
-\end{array}$ & $\begin{array}{l}\mathrm{na} \\
\text { na } \\
\text { na } \\
\mathrm{t}(48)=3.23, \mathrm{p}=0.002\end{array}$ \\
\hline $\mathrm{Fe}$ & $\begin{array}{l}\text { serum } \\
\text { plasma } \\
\text { whole blood } \\
\text { hair } \\
\end{array}$ & $\begin{array}{l}\text { none } \\
\text { none } \\
\text { none } \\
\log _{10}(x)\end{array}$ & $\begin{array}{l}r_{S}=-0.37, p=0.03 \\
- \\
- \\
r_{S}=-0.69, p<0.001\end{array}$ & $\begin{array}{l}- \\
- \\
- \\
-\end{array}$ & $\begin{array}{l}t(35)=-2.97, p=0.006 \\
t(16)=-3.55, p=0.002 \\
t(48)=-4.91, p<0.001\end{array}$ & $\begin{array}{l}\overline{-} \\
\text { na } \\
- \\
\mathrm{t}(48)=2.33, \mathrm{p}=0.02\end{array}$ & $\begin{array}{l}\text { na } \\
\text { na } \\
\text { na } \\
t(48)=3.89, p<0.001\end{array}$ \\
\hline Co & $\begin{array}{l}\text { serum } \\
\text { plasma } \\
\text { whole blood } \\
\text { hair } \\
\end{array}$ & $\begin{array}{l}\log _{10}(x) \\
\text { none } \\
\sqrt{x} \\
\log _{10}(x) \\
\end{array}$ & $\begin{array}{l}r_{s}=-0.55, p<0.001 \\
- \\
r_{S}=-0.57, p<0.001 \\
r_{S}=-0.64, p<0.001\end{array}$ & $\begin{array}{l}- \\
- \\
- \\
-\end{array}$ & $\begin{array}{l}- \\
- \\
- \\
t(48)=-5.42, p<0.001\end{array}$ & $\begin{array}{l}t(35)=4.39, p<0.001 \\
\text { na } \\
t(33)=2.45, p=0.02 \\
t(48)=3.27, p=0.002\end{array}$ & $\begin{array}{l}\text { na } \\
\text { na } \\
\text { na } \\
U=142, p<0.001\end{array}$ \\
\hline $\mathrm{Cu}$ & $\begin{array}{l}\text { serum } \\
\text { plasma } \\
\text { whole blood } \\
\text { hair } \\
\end{array}$ & $\begin{array}{l}\log _{10}(x) \\
\text { none } \\
\log _{10}(x) \\
\text { none }\end{array}$ & $\begin{array}{l}- \\
- \\
- \\
- \\
\end{array}$ & $\begin{array}{l}- \\
U\end{array}=10, p=0.04$ & $\begin{array}{l}- \\
- \\
- \\
- \\
- \\
\end{array}$ & $\begin{array}{l}- \\
\text { na } \\
\mathrm{t}(33)=2.24, p=0.03 \\
-\end{array}$ & $\begin{array}{l}\text { na } \\
\text { na } \\
\text { na } \\
-\end{array}$ \\
\hline $\mathrm{Zn}$ & $\begin{array}{l}\text { serum } \\
\text { plasma } \\
\text { whole blood } \\
\text { hair }\end{array}$ & $\begin{array}{l}\text { none } \\
\text { none } \\
\text { none } \\
\text { none }\end{array}$ & $\begin{array}{l}- \\
- \\
- \\
r_{S}=-0.50, p<0.001\end{array}$ & $\begin{array}{l}- \\
- \\
- \\
-\end{array}$ & $\begin{array}{l}- \\
t(16)=-2.71, p=0.01 \\
- \\
t(48)=-2.27, p=0.03\end{array}$ & $\begin{array}{l}- \\
\text { na } \\
t(33)=-2.12, p=0.04 \\
-\end{array}$ & $\begin{array}{l}\text { na } \\
\text { na } \\
\text { na } \\
-\end{array}$ \\
\hline Se & $\begin{array}{l}\text { serum } \\
\text { plasma } \\
\text { whole blood } \\
\text { hair } \\
\end{array}$ & $\begin{array}{l}\log _{10}(x) \\
\text { none } \\
\text { none } \\
\log _{10}(x)\end{array}$ & $\begin{array}{l}- \\
- \\
- \\
- \\
\end{array}$ & $\begin{array}{l}- \\
- \\
- \\
-\end{array}$ & $\begin{array}{l}- \\
- \\
- \\
- \\
\end{array}$ & $\begin{array}{l}- \\
\text { na } \\
- \\
-\end{array}$ & $\begin{array}{l}\text { na } \\
\text { na } \\
\text { na } \\
-\end{array}$ \\
\hline As & hair & $\log _{10}(x)$ & $r s=-0.30, p=0.05$ & - & $t(48)=-4.34, p<0.001$ & - & $\mathrm{t}(48)=2.07, \mathrm{p}=0.04$ \\
\hline Mo & serum & none & $r_{S}=-0.43, p=0.008$ & - & - & - & na \\
\hline
\end{tabular}




\begin{tabular}{|c|c|c|c|c|c|c|c|}
\hline & $\begin{array}{l}\text { plasma } \\
\text { whole blood } \\
\text { hair }\end{array}$ & $\begin{array}{l}\text { none } \\
\text { none } \\
\log _{10}(x)\end{array}$ & $\begin{array}{l}r_{s}=-0.56, p=0.01 \\
r_{S}=-0.56, p<0.001 \\
-\end{array}$ & $\begin{array}{l}- \\
- \\
-\end{array}$ & $\begin{array}{l}t(16)=-2.92, p=0.009 \\
-\end{array}$ & $\begin{array}{l}\text { na } \\
\mathrm{t}(33)=3.05, \mathrm{p}=0.004 \\
\mathrm{t}(48)=2.91, \mathrm{p}=0.006\end{array}$ & $\begin{array}{l}\text { na } \\
\text { na } \\
-\end{array}$ \\
\hline \multirow[t]{3}{*}{$\mathrm{Cd}$} & serum & none & - & - & $t(35)=-2.96, p=0.006$ & - & na \\
\hline & plasma & none & - & - & $t(16)=-2.93, p=0.01$ & na & na \\
\hline & hair & $\sqrt{x}$ & $r_{S}=-0.61, p<0.001$ & - & $\mathrm{U}=17, \mathrm{p}<0.001$ & - & $\mathrm{t}(48)=3.48, \mathrm{p}=0.001$ \\
\hline $\mathrm{Hg}$ & hair & $\sqrt{x}$ & - & - & $\mathrm{t}(48)=-2.47, \mathrm{p}=0.02$ & - & - \\
\hline \multirow[t]{4}{*}{$\mathrm{TI}$} & serum & $\log _{10}(x)$ & - & - & - & - & na \\
\hline & plasma & $\log _{10}(x)$ & - & - & - & na & na \\
\hline & whole blood & $1 / x$ & - & - & - & - & na \\
\hline & hair & $\sqrt{x}$ & $r_{S}=-0.57, p<0.001$ & - & $t(48)=-4.25, p<0.001$ & $\mathrm{t}(48)=4.47, \mathrm{p}<0.001$ & $\mathrm{t}(48)=2.68, p=0.01$ \\
\hline \multirow[t]{4}{*}{$\mathrm{Pb}$} & serum & $\log _{10}(x)$ & - & - & - & - & na \\
\hline & plasma & $\sqrt{x}$ & - & $t(16)=-2.50, p=0.02$ & - & na & na \\
\hline & whole blood & $\sqrt{x}$ & - & - & $\mathrm{U}=67, \mathrm{p}=0.02$ & - & na \\
\hline & hair & $\log _{10}(x)$ & $r_{S}=-0.40, p=0.008$ & - & $U=89, p<0.001$ & $\mathrm{t}(48)=2.38, \mathrm{p}=0.02$ & $\mathrm{U}=174, \mathrm{p}=0.01$ \\
\hline
\end{tabular}


Table A.4 Results of linear regression modelling revealing associations of biomarkers and metal(loid) levels with confounding factors in blood and hair of European brown bear (Ursus arctos)

\begin{tabular}{|c|c|c|c|c|c|c|c|c|}
\hline Variable & Compartment & Transformation & $\begin{array}{l}\text { Age } \\
b\end{array}$ & $\begin{array}{l}\text { Sex } \\
\text { male/female }\end{array}$ & $\begin{array}{l}\text { Status } \\
\text { captive/free-ranging }\end{array}$ & $\begin{array}{l}\text { Country } \\
\text { Croatia/Poland }\end{array}$ & $\begin{array}{l}\text { Hair growth phase } \\
\text { growth/quiescent }\end{array}$ & $R$-squared \\
\hline MT & serum & none & -0.04 & 0.33 & 0.06 & na & na & 0.12 \\
\hline MDA & serum & $\log _{10}(x)$ & 0.25 & -0.14 & 0.34 & na & na & 0.09 \\
\hline SOD & $\begin{array}{l}\text { serum } \\
\text { whole blood }\end{array}$ & $\begin{array}{l}\text { none } \\
\log _{10}(x)\end{array}$ & $\begin{array}{l}-0.45^{\star} \\
-0.04\end{array}$ & $\begin{array}{l}\mathbf{0 . 3 5 ^ { \star }} \\
-0.16\end{array}$ & $\begin{array}{l}0.03 \\
0.40^{\star}\end{array}$ & $\begin{array}{l}\text { na } \\
\text { na }\end{array}$ & $\begin{array}{l}\text { na } \\
\text { na }\end{array}$ & $\begin{array}{l}0.34 \\
0.18\end{array}$ \\
\hline $\mathrm{Mg}$ & $\begin{array}{l}\text { serum } \\
\text { whole blood } \\
\text { hair }\end{array}$ & $\begin{array}{l}\text { none } \\
\text { none } \\
\sqrt{x}\end{array}$ & $\begin{array}{l}-0.18 \\
-0.31 \\
-0.23\end{array}$ & $\begin{array}{l}\mathbf{0 . 3 8}^{\star} \\
0.02 \\
0.01\end{array}$ & 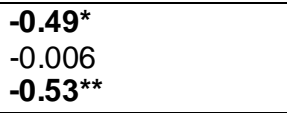 & $\begin{array}{l}\text { na } \\
\text { na } \\
-0.05\end{array}$ & $\begin{array}{l}\text { na } \\
\text { na } \\
-0.10\end{array}$ & $\begin{array}{l}0.26 \\
0.09 \\
0.17\end{array}$ \\
\hline $\mathrm{Ca}$ & $\begin{array}{l}\text { serum } \\
\text { whole blood } \\
\text { hair }\end{array}$ & $\begin{array}{l}\text { none } \\
\text { none } \\
\log _{10}(x)\end{array}$ & $\begin{array}{l}-0.27 \\
-0.20 \\
-0.17\end{array}$ & $\begin{array}{l}0.002 \\
-0.22 \\
0.02 \\
\end{array}$ & $\begin{array}{l}-0.17 \\
-0.23 \\
-0.87^{\star \star \star}\end{array}$ & $\begin{array}{l}\text { na } \\
\text { na } \\
0.14\end{array}$ & $\begin{array}{l}\text { na } \\
\text { na } \\
-0.07\end{array}$ & $\begin{array}{l}0.04 \\
0.11 \\
0.56\end{array}$ \\
\hline $\mathrm{Mn}$ & $\begin{array}{l}\text { serum } \\
\text { whole blood } \\
\text { hair }\end{array}$ & $\begin{array}{l}\log _{10}(x) \\
\text { none } \\
\log _{10}(x)\end{array}$ & $\begin{array}{l}0.10 \\
0.30 \\
-0.35^{\star}\end{array}$ & $\begin{array}{l}\mathbf{0 . 3 2 *} \\
\mathbf{0 . 3 8 ^ { * }} \\
-0.13\end{array}$ & $\begin{array}{l}\mathbf{0 . 5 4}{ }^{\star} \\
\mathbf{0 . 4 4}^{\star} \\
0.26\end{array}$ & $\begin{array}{l}\mathrm{na} \\
\mathrm{na} \\
0.02\end{array}$ & $\begin{array}{l}\mathrm{na} \\
\text { na } \\
-0.24\end{array}$ & $\begin{array}{l}0.35 \\
0.35 \\
0.52\end{array}$ \\
\hline $\mathrm{Fe}$ & $\begin{array}{l}\text { serum } \\
\text { whole blood } \\
\text { hair }\end{array}$ & $\begin{array}{l}\text { none } \\
\text { none } \\
\log _{10}(x)\end{array}$ & $\begin{array}{l}-0.15 \\
-0.09 \\
-0.37^{\text {}}\end{array}$ & $\begin{array}{l}0.07 \\
0.22 \\
-0.06\end{array}$ & $\begin{array}{l}0.35 \\
0.25 \\
0.22\end{array}$ & $\begin{array}{l}\mathrm{na} \\
\mathrm{na} \\
-0.13\end{array}$ & $\begin{array}{l}\text { na } \\
\text { na } \\
-0.32^{\star}\end{array}$ & $\begin{array}{l}0.22 \\
0.14 \\
0.64\end{array}$ \\
\hline Co & $\begin{array}{l}\text { serum } \\
\text { whole blood } \\
\text { hair }\end{array}$ & $\begin{array}{l}\log _{10}(x) \\
\sqrt{x} \\
\log _{10}(x)\end{array}$ & $\begin{array}{l}-0.48^{\star} \\
-0.49^{\star \star} \\
-0.25^{\star}\end{array}$ & $\begin{array}{l}0.12 \\
-0.001 \\
-0.18\end{array}$ & $\begin{array}{l}-0.003 \\
0.02 \\
\mathbf{0 . 3 3}^{\text {** }}\end{array}$ & $\begin{array}{l}\text { na } \\
\text { na } \\
-0.21^{*}\end{array}$ & $\begin{array}{l}\text { na } \\
\text { na } \\
-0.25^{\star}\end{array}$ & $\begin{array}{l}0.23 \\
0.25 \\
0.69 \\
\end{array}$ \\
\hline $\mathrm{Cu}$ & $\begin{array}{l}\text { serum } \\
\text { whole blood } \\
\text { hair }\end{array}$ & $\begin{array}{l}\log _{10}(x) \\
\log _{10}(x) \\
\text { none }\end{array}$ & $\begin{array}{l}-0.03 \\
0.16 \\
-0.31\end{array}$ & $\begin{array}{l}-0.28 \\
-0.37^{\star} \\
0.20\end{array}$ & $\begin{array}{l}0.11 \\
0.28 \\
-0.12\end{array}$ & $\begin{array}{l}\text { na } \\
\text { na } \\
-0.10\end{array}$ & $\begin{array}{l}\text { na } \\
\text { na } \\
0.08\end{array}$ & $\begin{array}{l}0.09 \\
0.19 \\
0.09\end{array}$ \\
\hline $\mathrm{Zn}$ & $\begin{array}{l}\text { serum } \\
\text { whole blood } \\
\text { hair }\end{array}$ & $\begin{array}{l}\text { none } \\
\text { none } \\
\text { none }\end{array}$ & $\begin{array}{l}0.25 \\
-0.33\end{array}$ & -0.13 & $\begin{array}{l}\mathbf{0 . 4 6 ^ { \star }} \\
0.16\end{array}$ & $\begin{array}{l}\text { na } \\
-0.09\end{array}$ & $\begin{array}{l}\mathrm{na} \\
0.06\end{array}$ & $\begin{array}{l}0.13 \\
\mathrm{na} \\
0.20\end{array}$ \\
\hline $\mathrm{Se}$ & $\begin{array}{l}\text { serum } \\
\text { whole blood } \\
\text { hair }\end{array}$ & $\begin{array}{l}\log _{10}(x) \\
\text { none } \\
\log _{10}(x)\end{array}$ & $\begin{array}{l}-0.26 \\
-0.32 \\
0.16\end{array}$ & $\begin{array}{l}0.12 \\
\mathbf{0 . 3 4} \\
-0.21\end{array}$ & $\begin{array}{l}-0.19 \\
-0.09 \\
-0.02\end{array}$ & $\begin{array}{l}\text { na } \\
\text { na } \\
-0.33^{*}\end{array}$ & $\begin{array}{l}\text { na } \\
\text { na } \\
0.33\end{array}$ & $\begin{array}{l}0.04 \\
0.18 \\
0.22\end{array}$ \\
\hline As & hair & $\log _{10}(x)$ & & & & & & na \\
\hline Mo & $\begin{array}{l}\text { serum } \\
\text { whole blood } \\
\text { hair }\end{array}$ & $\begin{array}{l}\text { none } \\
\text { none } \\
\log _{10}(x)\end{array}$ & $\begin{array}{l}-0.50^{\star} \\
-0.65^{\star \star \star} \\
0.06\end{array}$ & $\begin{array}{l}0.22 \\
-0.07 \\
-0.27\end{array}$ & $\begin{array}{l}-0.08 \\
-0.22 \\
-0.03\end{array}$ & $\begin{array}{l}\text { na } \\
\text { na } \\
-0.41^{*}\end{array}$ & $\begin{array}{l}\mathrm{na} \\
\mathrm{na} \\
0.14\end{array}$ & $\begin{array}{l}0.23 \\
0.36 \\
0.25\end{array}$ \\
\hline $\mathrm{Cd}$ & $\begin{array}{l}\text { serum } \\
\text { hair }\end{array}$ & $\sqrt{x}$ & $\begin{array}{l}0.12 \\
-0.15\end{array}$ & $\begin{array}{l}0.11 \\
0.01\end{array}$ & $\begin{array}{l}0.54^{\star} \\
0.53^{\star \star \star}\end{array}$ & $\begin{array}{l}\text { na } \\
-0.08\end{array}$ & $\begin{array}{l}\text { na } \\
-0.18\end{array}$ & $\begin{array}{l}0.24 \\
0.59\end{array}$ \\
\hline $\mathrm{Hg}$ & hair & $\sqrt{x}$ & -0.04 & -0.21 & 0.38 & -0.04 & 0.16 & 0.17 \\
\hline $\mathrm{TI}$ & $\begin{array}{l}\text { serum } \\
\text { whole blood }\end{array}$ & $\begin{array}{l}\log _{10}(x) \\
1 / x\end{array}$ & $\begin{array}{l}-0.03 \\
-0.07\end{array}$ & $\begin{array}{l}-0.18 \\
0.21\end{array}$ & $\begin{array}{l}-0.06 \\
-0.22\end{array}$ & $\begin{array}{l}\text { na } \\
\text { na }\end{array}$ & $\begin{array}{l}\text { na } \\
\text { na }\end{array}$ & $\begin{array}{l}0.04 \\
0.08\end{array}$ \\
\hline
\end{tabular}




\begin{tabular}{|c|c|c|c|c|c|c|c|c|}
\hline & hair & $\sqrt{x}$ & -0.23 & 0.04 & $0.34^{*}$ & $-0.48^{\star \star \star}$ & -0.06 & 0.66 \\
\hline \multirow[t]{3}{*}{$\mathrm{Pb}$} & serum & $\log _{10}(x)$ & 0.18 & 0.13 & 0.20 & na & na & 0.05 \\
\hline & whole blood & & 0.20 & 0.26 & 0.34 & na & na & 0.18 \\
\hline & hair & $\log _{10}(x)$ & -0.10 & -0.06 & $0.39^{*}$ & -0.16 & -0.21 & 0.45 \\
\hline
\end{tabular}

MT-metallothionein, MDA- malondialdehyde, SOD- superoxide-dismutase, $b$-standardized multiple regression coefficient, ${ }^{*} p<0.05,{ }^{* *} p<0.01,{ }^{* * *} p<0.001$, na- non applicable (factor not included in the model or conditions for regression analyses not fulfilled: $\mathrm{Zn}$ in whole blood, As in hair). Number of MT data is 31(N=31), MDA N=35, serum SOD N=37, whole blood $\mathrm{SOD} N=35$, metal(loid) data for serum $\mathrm{N}=37$, plasma $\mathrm{N}=18$, whole blood $\mathrm{N}=35$, hair $\mathrm{N}=50$. Sex was coded as 1 for males and 2 for females; status was coded as 1 for captive and 2 for
free-ranging bears; country was coded as 1 for Croatia and 2 for Poland; hair growth phase was coded as 1 for growth and 2 for quiescent 
Table A.5 Results of linear regression modelling revealing associations between biomarkers and metal(loid) levels in blood of European brown bear (Ursus arctos), based only on significant confounding factors from Table A.4

\begin{tabular}{|c|c|c|c|c|c|}
\hline $\begin{array}{l}\text { Dependent } \\
\text { variable }\end{array}$ & $\begin{array}{l}\text { Independent } \\
\text { variable }\end{array}$ & $\mathrm{N}$ & $b$ & $p$-value & $R$-squared \\
\hline \multirow[t]{7}{*}{ Cd serum } & $\begin{array}{l}\text { MT serum } \\
\text { status }\end{array}$ & 29 & & & na \\
\hline & $\begin{array}{l}\text { MDA } \\
\text { status }\end{array}$ & 34 & & & na \\
\hline & SOD serum & 35 & -0.21 & 0.28 & 0.25 \\
\hline & age & & 0.08 & 0.75 & \\
\hline & sex & & 0.11 & 0.55 & \\
\hline & status & & 0.59 & 0.03 & \\
\hline & $\begin{array}{l}\text { SOD whole blood } \\
\text { status }\end{array}$ & 29 & $\begin{array}{l}-0.38 \\
0.58\end{array}$ & $\begin{array}{l}0.05 \\
0.004\end{array}$ & 0.33 \\
\hline \multirow[t]{4}{*}{ TI serum } & SOD serum & 35 & 0.13 & 0.54 & 0.07 \\
\hline & age & & 0.02 & 0.90 & \\
\hline & sex & & -0.28 & 0.16 & \\
\hline & $\begin{array}{l}\text { SOD whole blood } \\
\text { status }\end{array}$ & 29 & $\begin{array}{l}-0.19 \\
-0.004\end{array}$ & $\begin{array}{l}0.38 \\
0.98\end{array}$ & 0.04 \\
\hline \multirow[t]{5}{*}{ TI whole blood } & SOD serum & 29 & -0.04 & 0.89 & 0.07 \\
\hline & age & & 0.03 & 0.89 & \\
\hline & sex & & 0.26 & 0.24 & \\
\hline & SOD whole blood & 35 & 0.04 & 0.86 & 0.03 \\
\hline & status & & -0.18 & 0.36 & \\
\hline \multirow[t]{5}{*}{ Pb serum } & SOD serum & 35 & 0.30 & 0.17 & 0.13 \\
\hline & age & & 0.19 & 0.35 & \\
\hline & sex & & 0.12 & 0.54 & \\
\hline & SOD whole blood & 29 & 0.47 & 0.04 & 0.19 \\
\hline & status & & -0.06 & 0.78 & \\
\hline \multirow[t]{5}{*}{$\mathrm{Pb}$ whole blood } & SOD serum & 29 & -0.01 & 0.97 & 0.13 \\
\hline & age & & 0.11 & 0.64 & \\
\hline & sex & & 0.34 & 0.12 & \\
\hline & SOD whole blood & 35 & 0.28 & 0.13 & 0.23 \\
\hline & status & & 0.29 & 0.12 & \\
\hline
\end{tabular}

MT-metallothionein, MDA- malondialdehyde, SOD- superoxide-dismutase, $b$-standardized multiple regression coefficient, na- non applicable (conditions for regression analyses not fulfilled). Sex was coded as 1 for males and 2 for females; status was coded as 1 for captive and 2 for free-ranging bears. Some variables are transformed: SOD whole blood $\left(\log _{10}(x)\right)$, $\mathrm{TI}$ serum $\left(\log _{10}(\mathrm{x})\right)$, TI whole blood $(1 / \mathrm{x}), \mathrm{Pb}$ serum $\left(\log _{10}(\mathrm{x})\right)$ and $\mathrm{Pb}$ whole blood $(\sqrt{x})$ 
Table A.6 Serum and whole blood (mean \pm SD (range) median) metal(loid) levels of European brown bears (Ursus arctos) categorized by status

\begin{tabular}{|c|c|c|c|c|}
\hline & $\begin{array}{l}\text { Serum } \\
\text { Free-ranging }(\mathrm{N}=27)\end{array}$ & Captive $(\mathrm{N}=10)$ & $\begin{array}{l}\text { Whole blood } \\
\text { Free-ranging }(\mathrm{N}=26)\end{array}$ & Captive $(\mathrm{N}=9)$ \\
\hline $\mathrm{Mg}(\mathrm{mg} / \mathrm{L})$ & $18.8 \pm 2.0(15.5-23.1) 18.9$ & $20.3 \pm 1.7(17.7-24.0) 20.3$ & $21.5 \pm 3.1(17.0-28.5) 21.2$ & $20.6 \pm 3.1(16.2-25.4) 19.8$ \\
\hline $\mathrm{Ca}(\mathrm{mg} / \mathrm{L})$ & $91.6 \pm 8.0(69.3-104) 92.7$ & $91.6 \pm 8.5(81.9-110) 92.1$ & $30.9 \pm 4.9(18.8-44.1) 31.2$ & $33.0 \pm 10.7(22.5-48.6) 28.9$ \\
\hline $\mathrm{Mn}(\mu \mathrm{g} / \mathrm{L})$ & $3.80 \pm 1.37(1.91-7.66) 3.60$ & $2.56 \pm 0.62(1.68-3.97) 2.42$ & $23.6 \pm 6.7(9.35-34.2) 23.4$ & $18.0 \pm 7.8(9.22-26.4) 18.1$ \\
\hline $\mathrm{Fe}(\mathrm{mg} / \mathrm{L})$ & $7.57 \pm 3.49(2.26-17.5) 6.57$ & $3.98 \pm 2.41(0.594-9.29) 4.37$ & $363 \pm 50(239-449) 356$ & $328 \pm 65(195-422) 350$ \\
\hline Co $(\mu g / L)$ & $0.862 \pm 0.597(0.151-2.55) 0.689$ & $0.565 \pm 0.482(0.130-1.46) 0.286$ & $0.348 \pm 0.270(0.074-1.10) 0.269$ & $0.253 \pm 0.275(0.074-0.812) 0.0744$ \\
\hline $\mathrm{Cu}(\mathrm{mg} / \mathrm{L})$ & $0.789 \pm 0.401(0.351-2.05) 0.680$ & $0.803 \pm 0.667(0.326-2.34) 0.499$ & $0.480 \pm 0.158(0.312-0.901) 0.406$ & $0.452 \pm 0.272(0.225-1.04) 0.344$ \\
\hline $\mathrm{Zn}(\mathrm{mg} / \mathrm{L})$ & $1.35 \pm 0.28(0.949-1.84) 1.31$ & $1.18 \pm 0.19(0.719-1.42) 1.18$ & $2.06 \pm 0.28(1.48-2.66) 2.03$ & $1.86 \pm 0.27(1.63-2.56) 1.78$ \\
\hline As $(\mu \mathrm{g} / \mathrm{L})$ & $(<0.678-1.50)^{1}$ & $0.684 \pm 0.570(<0.678-2.11)<0.678^{2}$ & $<2.37-2.49^{3}$ & $<2.37^{4}$ \\
\hline $\operatorname{Se}(\mu g / L)$ & $114 \pm 27(72.7-207) 110$ & $113 \pm 18(92.7-156) 107$ & $142 \pm 28(80.2-195) 142$ & $137 \pm 36(94.2-204) 123$ \\
\hline Mo $(\mu \mathrm{g} / \mathrm{L})$ & $52.5 \pm 9.8(38.4-71.2) 49.6$ & $46.6 \pm 12.2(22.6-65.1) 45.1$ & $13.5 \pm 4.7(3.38-23.3) 14.1$ & $13.0 \pm 4.2(8.58-19.7) 11.5$ \\
\hline $\mathrm{Cd}(\mu \mathrm{g} / \mathrm{L})$ & $0.120 \pm 0.046(<0.070-0.248) 0.111^{5}$ & $0.073 \pm 0.035(<0.070-0.129) 0.078^{6}$ & $0.298 \pm 0.260(<0.247-1.21)<0.247^{7}$ & $<0.247^{8}$ \\
\hline $\mathrm{Hg}(\mu \mathrm{g} / \mathrm{L})$ & $(<0.375-1.11)^{9}$ & $<0.375^{10}$ & $1.41 \pm 1.49(<1.31-6.32)<1.31^{11}$ & $<1.31^{12}$ \\
\hline $\mathrm{TI}(\mu \mathrm{g} / \mathrm{L})$ & $0.050 \pm 0.043(<0.009-0.158) 0.035^{13}$ & $0.048 \pm 0.027(<0.009-0.087) 0.049^{14}$ & $0.067 \pm 0.031(0.032-0.141) 0.053$ & $0.052 \pm 0.013(0.036-0.073) 0.054$ \\
\hline $\mathrm{Pb}(\mu \mathrm{g} / \mathrm{L})$ & $0.893 \pm 0.538(0.389-2.63) 0.691$ & $1.07 \pm 0.99(0.147-3.14) 0.858$ & $61.2 \pm 25.5(27.7-139) 64.0$ & $49.2 \pm 53.0(5.08-168) 29.6$ \\
\hline
\end{tabular}

$120 / 27<$ As MDL $(0.678 \mu \mathrm{g} / \mathrm{L}$ serum $) ;{ }^{2} 6 / 10<$ As MDL $\left(0.678 \mu \mathrm{g} / \mathrm{L}\right.$ serum); ${ }^{3} 24 / 26<\mathrm{As} \mathrm{MDL}(2.37 \mu \mathrm{g} / \mathrm{L} \mathrm{blood}) ; 4 \mathrm{~g} / 9<\mathrm{As} \mathrm{MDL}(2.37 \mu \mathrm{g} / \mathrm{L} \mathrm{blood})$

${ }^{9} 22 / 27<\mathrm{Hg}$ MDL $(0.375 \mu \mathrm{g} / \mathrm{L}$ serum $) ; 1010 / 10<\mathrm{Hg} \mathrm{MDL}(0.375 \mu \mathrm{g} / \mathrm{L}$ serum $) ;{ }^{11} 18 / 26<\mathrm{Hg}$ MDL $(1.31 \mu \mathrm{g} / \mathrm{L}$ blood $) ;{ }^{12} \mathrm{~g} / 9<\mathrm{Hg} \mathrm{MDL}(1.31 \mu \mathrm{g} / \mathrm{L} \mathrm{blood})$

${ }^{13} 2 / 27<\mathrm{TI}$ MDL $(0.009 \mu \mathrm{g} / \mathrm{L}$ serum $) ;{ }^{14} 1 / 10<\mathrm{TI} \mathrm{MDL}(0.009 \mu \mathrm{g} / \mathrm{L}$ serum $)$ 
Table A.7 Results of linear regression modelling revealing associations of non-essential metal levels between blood and hair of European brown bear (Ursus arctos), based only on significant confounding factors from Table A.4

\begin{tabular}{llllll}
\hline $\begin{array}{l}\text { Dependent } \\
\text { variable }\end{array}$ & $\begin{array}{l}\text { Independent } \\
\text { variable }\end{array}$ & $\mathrm{N}$ & $b$ & $p$-value & $R$-squared \\
\hline Cd serum & Cd hair & 28 & -0.01 & 0.97 & 0.13 \\
& status & & 0.37 & 0.18 & \\
\hline TI serum & TI hair & 28 & 0.39 & 0.17 & 0.09 \\
& status & & -0.21 & 0.38 & \\
& country & & 0.15 & 0.56 & \\
TI whole blood & TI hair & 30 & 0.17 & 0.52 & 0.10 \\
& status & & -0.22 & 0.33 & \\
& country & & 0.33 & 0.19 & \\
\hline Pb serum & Pb hair & 28 & 0.30 & 0.18 & 0.09 \\
& status & & -0.24 & 0.27 & \\
Pb whole blood & Pb hair & 30 & 0.07 & 0.76 & 0.09 \\
& status & & 0.27 & 0.21 & \\
\hline
\end{tabular}

b-standardized multiple regression coefficient. Status was coded as 1 for captive and 2 for free-ranging bears; country was coded as 1 for Croatia and 2 for Poland. Some variables are transformed: Cd hair $(\sqrt{x})$, TI serum $\left(\log _{10}(x)\right)$, TI whole blood $(1 / x)$, TI hair $(\sqrt{x}), \mathrm{Pb}$ serum and hair $\left(\log _{10}(\mathrm{x})\right), \mathrm{Pb}$ whole blood $(\sqrt{x})$ 
